\title{
Mechanisms of Reciprocal Regulation of Gonadotropin-Releasing Hormone (GnRH)-Producing and Immune Systems: The Role of GnRH, Cytokines and Their Receptors in Early Ontogenesis in Normal and Pathological Conditions
}

\author{
Liudmila Zakharova, Viktoria Sharova *(D) and Marina Izvolskaia \\ Koltsov Institute of Developmental Biology, The Russian Academy of Sciences, 119334 Moscow, Russia; \\ 1-a-zakharova@mail.ru (L.Z.); izvolskaya@hotmail.com (M.I.) \\ * Correspondence: sarovav@mail.ru
}

check for updates

Citation: Zakharova, L.; Sharova, V.; Izvolskaia, M. Mechanisms of Reciprocal Regulation of Gonadotropin-Releasing Hormone (GnRH)-Producing and Immune Systems: The Role of GnRH, Cytokines and Their Receptors in Early Ontogenesis in Normal and Pathological Conditions. Int. J. Mol. Sci. 2021, 22, 114. https://dx.doi.org/ 10.3390/ijms22010114

Received: 25 October 2020

Accepted: 22 December 2020

Published: 24 December 2020

Publisher's Note: MDPI stays neutral with regard to jurisdictional claims in published maps and institutional affiliations.

Copyright: (c) 2020 by the authors. Licensee MDPI, Basel, Switzerland. This article is an open access article distributed under the terms and conditions of the Creative Commons Attribution (CC BY) license (https: / / creativecommons.org/ licenses/by/4.0/).

\begin{abstract}
Different aspects of the reciprocal regulatory influence on the development of gonadotropinreleasing hormone $(\mathrm{GnRH})$-producing- and immune systems in the perinatal ontogenesis and their functioning in adults in normal and pathological conditions are discussed. The influence of GnRH on the development of the immune system, on the one hand, and the influence of proinflammatory cytokines on the development of the hypothalamic-pituitary-gonadal system, on the other hand, and their functioning in adult offspring are analyzed. We have focused on the effects of GnRH on the formation and functional activity of the thymus, as the central organ of the immune system, in the perinatal period. The main mechanisms of reciprocal regulation of these systems are discussed. The reproductive health of an individual is programmed by the establishment and development of physiological systems during critical periods. Regulatory epigenetic mechanisms of development are not strictly genetically controlled. These processes are characterized by a high sensitivity to various regulatory factors, which provides possible corrections for disorders.
\end{abstract}

Keywords: early ontogenesis; GnRH neuron migration; HPG and immune systems; thymic development; GnRH receptors; signal molecules; perinatal programming

\section{Introduction}

It is currently believed that the reciprocal regulation of the hypothalamic-pituitarygonadal (HPG) and immune systems is laid down already at the initial stages of their development and is controlled by neuropeptides, hormones, neurotransmitters, and immunomediators throughout the entire period of life [1-7]. The signals generated by the HPG axis, the main participants of which are gonadotropin-releasing hormone (GnRH), gonadotropins, and sex steroids [8], coordinate the development and functioning of the immune system, and immunomediators, in particular, cytokines and thymic peptides, influence the HPG axis [2]. The health of the adult offspring depends on how these interactions are formed and developed in the early, critical periods of ontogenesis, when the structure and functions of the HPG and immune systems are formed and epigenetic mechanisms are implemented that ensure their adaptive plasticity [2,9]. During early development, neurohormones, including GnRH, begin to be synthesized in fetal tissues before neural transmission is formed. They are found in the general blood circulation in high concentrations and carry out not only regulatory, but also morphogenetic functions [6,10-12]. During development, different signal molecules, specifically, serotonin and noradrenaline [13], semaphorins [14,15], gamma-aminobutyric acid (GABA) [16], involved in the regulation of the functions of the GnRH system of mature individuals are able to influence the migration of GnRH neurons, depending on their spatial or temporal location.

The initial activation of the HPG axis by GnRH occurs in utero, then in the early postnatal and pubertal periods. The initiation of puberty is associated with the activation of 
the HPG axis as a result of impulse secretion of GnRH in the hypothalamus [5,8,17]. Axons of GnRH neurons release GnRH into the portal system with a certain frequency, creating in it the concentration necessary to start secreting gonadotropins, which, in turn, stimulate the secretion of sex steroids. The key regulator of GnRH secretion is the KISS1 gene product kisspeptin (KISS1) and its receptor (KISS1R) [18]. The main form of the kisspeptin family, kisspeptin-54, contains a decapeptide that determines the functions of this family after binding to the specific receptor GPR54 (G protein receptor 54) or KISS1R [19-21].

The mechanism of GnRH secretion regulation in the hypothalamus includes a network of various neurons, including KISS1-producing ones, which can act on GnRH neurons through separate or multiple neuronal systems [22,23]. GnRH- and KISS1 neurons are located in the same regions of the hypothalamus, and GnRH neurons express KISS1R [18,24]. Axons of KISS1 neurons form pericapillary plexuses at the site of GnRH secretion [25]. Neurokinin B (NKB) and dynorphin, which colocalize with KISS1 in the arcuate nucleus and are linked by axosomatic synapses, are also involved in the generation of GnRH impulses [26]. It is assumed that NKB initiates the onset of GnRH impulse secretion, while dynorphin initiates its termination [27]. General cues of GnRH neuron regulation in HPG axis is presented on Figure 1.

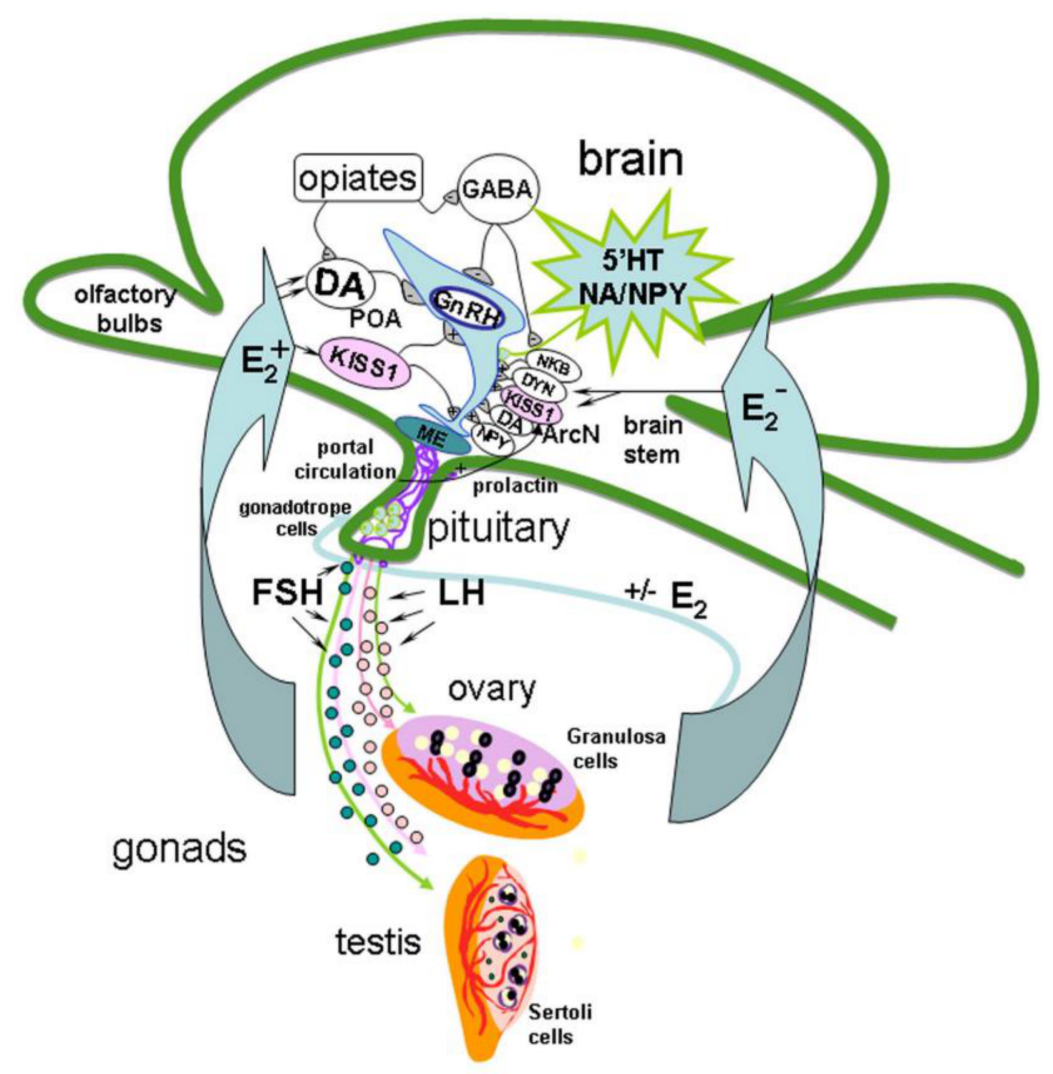

Figure 1. Model of the gonadotropin-releasing hormone $(\mathrm{GnRH})$ neuron regulation in hypothalamicpituitary-gonadal axis in adults. The mechanism of $\mathrm{GnRH}$ secretion regulation in the hypothalamus includes different signal molecules produced in different brain regions such as preoptic area (POA), locus coeruleus, raphe nucleus and brain stem, in particularly, serotonin $\left(5^{\prime} \mathrm{HT}\right)$, dopamine (DA), noradrenaline (NA), gamma-aminobutyric acid (GABA), kisspeptin (KISS1), neuropeptide Y (NPY), opiates, neurokinin B (NKB) and dynorphin (DYN), which colocalize with KISS1 in the arcuate nucleus (ArcN), are also involved in the generation of GnRH impulses. NKB initiates the onset of GnRH impulse secretion in median eminence (ME), and DYN initiates its termination. In turn, axons of GnRH neurons release GnRH into the portal system in necessary concentration to trigger luteinizing hormone ( $\mathrm{LH})$ and follicle-stimulating hormone (FSH) secretion, which stimulate the secretion of sex steroids. Sex steroids, in turn, regulate the GnRH and LH synthesis in the brain and pituitary. 
Along with the modulation of gonadotropins, GnRH is also involved in the modulation of sexual behavior, transmission of olfactory signals, and the formation and functioning of the immune system $[2,28,29]$. A variety of $\mathrm{GnRH}$ forms with different origins, structures, and functional significance have been revealed [29]. In all amniotes at least two GnRH forms are present (GnRH1 and GnRH2), which are encoded by separate genes and, despite their comparable cDNA and genomic structures, are clearly distinguished [30,31]. They mediate their effects through specific receptors associated with the transmembrane $G$ protein. In humans the hypothalamic GnRH regulates gonadotropin secretion through the pituitary GnRH type I receptor via activation of $\mathrm{G}(\mathrm{q})$ [32]. In addition to the brain, expression of GnRHs and/or their receptors (GnRHRs) was also detected in the liver, heart, skeletal muscles, kidneys, mammary gland, testes, ovaries, prostate, endometrium, placenta during pregnancy, and in cells of immune system, in the splenocytes, thymocytes and peripheral blood T-cells, both $\mathrm{CD}^{+}$and $\mathrm{CD}^{+}$subsets, at different stages of ontogenesis [3,6,11,28,33,34].

The main source and target of circulating GnRH1 are the hypothalamus and the pituitary gland. Its functions are realized through endocrine mechanisms, while the functions of extracerebral GnRHs, which are synthesized locally, are apparently associated with autocrine and/or paracrine regulation [31,35]. In the thymus and spleen GnRH modulates the proliferation of various subpopulations of $\mathrm{T}$ lymphocytes, the activation of natural killer cells and the synthesis of cytokines $[2,3,6]$.

In turn, immunomediators, in particular, cytokines, are modulators of the development of various brain structures, including the GnRH system, as well as modulators of steroidogenesis and gonadal functions in males and females [36,37]. In adults, cytokines are involved in maintaining homeostasis and regulating immune responses not only in the immune system at the periphery, but also in the brain. In the neurons and glial tissue of the brain, the expression of cytokines and their receptors, which are identical or closely related to the cytokines synthesized by the peripheral immune system, were detected. They affect the number and the so-called "immunocompetence" of nerve cells [38,39].

Bacterial or viral activation of the mother's immune system during pregnancy leads to the development of systemic inflammation, characterized by an increase in the synthesis of proinflammatory cytokines, which have a negative effect on the development of the fetal brain $[37,39-47]$. The changes occurring in the brain lead to disorders in the development of the nervous and endocrine systems, including HPG, a decrease in reproductive capacity or infertility in adult offspring [40,46,48-50]. At present, a sufficient amount of data has appeared to prove that inflammation of the central nervous system (CNS) is associated with almost all neurological diseases that develop in remote periods of life [51-55]. Neuroinflammation can be generated by signals from cytokines and cells of the immune system migrating to the CNS from the periphery, as well as cytokines synthesized locally in the brain [47-56]. Cytokines can realize their effects both by direct influence on GnRH neurons through specific receptors, and indirectly, through the secretion of other mediators such as opioids, prostaglandins, catecholamines, GABA, glutamate, and nitric oxide (NO) [57-59].

The regulation of the processes of formation of physiological systems is characterized by lability and sensitivity to many regulatory factors. This opens up opportunities for correcting impairments of the development and functioning of the HPG system.

In our studies, we tried to reveal the role of GnRH in thymus development and possible mechanisms underlying the GnRH effects in early development, in particular, its influence on the cytokine expression in the fetal thymus in rodents, on the one hand, and the influence of cytokines on the development of the HPG system, on the other hand. In addition, long-term effects of prenatal GnRH deficiency on the functions of the immune system, and the influence of prenatal inflammation induced by bacterial lipopolysaccharide (LPS) on development and functioning of HPG system were studied. We are also searching approaches to reversing reproductive disorders induced by systemic inflammation in early ontogenesis.

This review article presents an analysis of our own and published data on possible mechanisms of regulation of the development and functioning of the GnRH-producing 
and immune systems in ontogenesis, the role of $\mathrm{GnRH}$, cytokines and other signaling molecules, and their receptors in these processes in health and disease.

\section{Effects of Different Signal Molecules on the Normal Development of the GnRH System}

In vertebrates, most of the GnRH neurons are formed in the prenatal period outside the brain from the epithelium of the olfactory placodes and regulatory or morphogenetic factors are involved in the differentiation of these placodes [60]. Then GnRH neurons migrate to the forebrain, where they are also located in adults. Signaling molecules affecting the development of $\mathrm{GnRH}$ neurons are usually divided into groups according to functions closely related to the sites of origin, migration, and definitive location of neurons. At least five groups of signaling molecules are distinguished: (1) cell adhesion molecules, (2) soluble guidance-cue factors, (3) cytokines, (4) neurotransmitters, and (5) transcription factors (Figure 2).

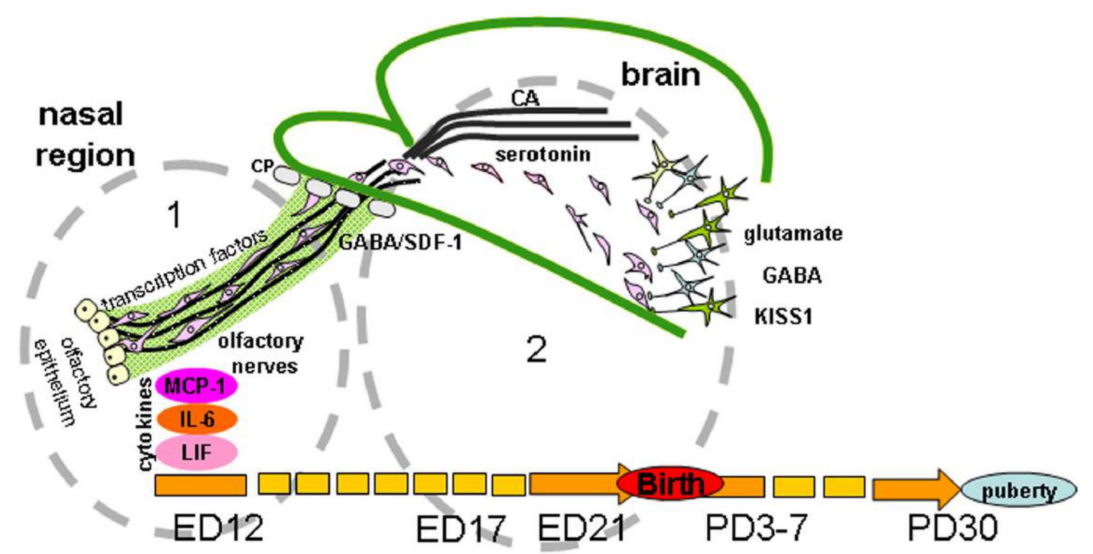

Figure 2. Regulation of gonadotropin-releasing hormone $(\mathrm{GnRH})$ neuron migration in nasal region (1) and brain (2) during development. GnRH neurons originate outside the brain in nasal olfactory epithelium and later neurons migrate using the surface of olfactory/terminal/vomeronasal nerves through the cribriform plate of the ethmoid bone (CP) to the forebrain on embryonic days (ED) 11-15 in mice and ED 12-17 in rats. Their migration is orchestrated by different signal molecules, such as cell adhesion molecules (polysialylated neural cell adhesion molecules (NCAM) in rats or peripherin in mice), soluble guidance-cue factors (semaphorins, Slit proteins, netrins, reelin, stromal cell-derived factor 1 (SDF-1), etc.), cytokines (monocyte chemoattractant protein-1 (MCP-1), interleukin-6 (IL-6), leukemia inhibitory factor (LIF)), neurotransmitters (gamma-aminobutyric acid (GABA), glutamate, monoamines (serotonin, catecholamines (CA)), and transcription factors (Pax6, AP-2 $\alpha$, Gli3, Ebf2 Nhlh2 VAX1 Mash-1, Math4A, Math4/neurogenin1, NeuroD, Olf-1, GATA-4). In rats, GnRH-neurons reach their final position on ED19 and after the receiving of correct afferent innervation they are capable of performing main function - to regulate the reproductive axis in adults. The same signal molecules can perform different functions or other molecules can be included at different stages of the development of the GnRH system. For instance, NCAM apparently participate in laying the route for GnRH neurons and do not play a key role in their migration. Transcription factors are involved in the initial stages of the differentiation of olfactory placodes and the precursors of GnRH neurons, cytokines in the development of olfactory structures and in the migration of GnRH neurons and GnRH secretion. Neurotransmitters take part in the migration of GnRH neurons mainly at the stage of their entry into the forebrain. Guidance-cue molecules are involved in the development of the olfactory system and contribute to directing the migration of GnRH neurons in the nasal head region and forebrain. Kisspeptin (KISS1) signaling is well demonstrated as a key component for the onset of puberty, GnRH neurons express KISS1 in embryonic mice brain. Moreover, KISS1 may inhibit GnRH neuronal movement and plays a role of stop molecule for GnRH neuronal migration. Abbreviation: PD—postnatal day. 
As noted above, GnRH neurons migrating in the nasal head region move along the olfactory, terminal, and vomeronasal nerves. After entering the forebrain, these neurons migrate caudally along a temporary projection of the vomeronasal nerve to the septopreoptic area [61]. The general pattern of GnRH system development is similar in most mammals, although there are natural differences in the timing of neuron formation and migration depending on the duration of pregnancy and the relative degree of offspring development at birth in individual species.

The process of migration is conventionally divided into three stages: (1) intranasal migration, (2) passage through the cribriform plate of the ethmoid bone, and (3) intracerebral migration (Figure 2). In normal development, each stage is characterized by a unique set of factors such as cell adhesion proteins, gradients of guidance-cue molecules, and a specific cellular microenvironment producing neurotransmitters and neuromodulators necessary for a successful migration of GnRH neurons. For example, suppression of $\beta 1$-integrin, which mediates the functions of cell adhesion proteins and guidance cues, impairs the migration of GnRH neurons in mouse fetuses, with a consequent delay in puberty and impairment of fertility in adult animals [62]. G-protein coupled receptors, in particular, prokineticin 2 (PROK2) and its receptor (PROKR2) were shown to modulate GnRH neuron migration. The mice null for PROKR2 had a loss of GnRH neurons in the forebrain on embryonic day 13.5 (ED13.5) and in adults, had formed a huge and tangled web of olfactory vomeronasal axons that would alter GnRH neuron movement [63].

\subsection{Adhesion Molecules}

In rats, GnRH neuron migration in the nasal head region is closely linked with fascicles of nerve fibers expressing polysialylated neural cell adhesion molecules (PSANCAM) [61]. Various experiments on the removal of NCAM from the migration route of GnRH neurons (using gene knockout, enzymatic treatment, or anti-NCAM antibodies) have shown that such interventions markedly reduce the number of migrating neurons but do not completely block their migration in rats [64-66]. Thus, NCAM apparently participate in laying the route for GnRH neurons but do not play a key role in their migration.

Moreover, it has been shown that these neurons in the nasal head region also migrate along nerve fibers expressing other cell adhesion proteins, namely, TAG-1 and CC-2 [61,67]. In mice, GnRH neurons appear to migrate along fascicles of nerve fibers expressing peripherin, an intermediate filament protein [68].

\subsection{Guidance-Cue Molecules}

It has been shown that a number of guidance-cue molecules participate in the development of the olfactory system. They include various chemoattractants, chemorepellents, and chemotrophic factors such as semaphorins, Slit proteins, netrins, reelin, etc. These factors guide the growth of olfactory nerve axons, and some of them supposedly contribute to directing the migration of GnRH neurons in the nasal head region and forebrain. The semaphorins play a critical role in GnRH neuron biology: on the one hand, regulating their migration and survival during embryonic development and, on the other hand, controlling the plasticity of the median eminence in terms of its response to varying sex steroid hormone levels $[14,15,69,70]$. For instance, SEMA 3A, SEMA 4D, SEMA 7A are responsible for vomeronasal axon guidance and GnRH neuron migration, SEMA 3E for neuron survival during the developmental period, and at the same time, SEMA 3A takes part in the median eminence plasticity and SEMA 7A in GnRH neuron plasticity in adults [71]. Mutations in 3 semaphorins (SEMA3A, SEMA3E, SEMA7A) and in their receptors (PLXNA1, NRP1, NRP2) have been found in isolated GnRH deficiency patients [15,71,72].

The secreted Slit glycoproteins (Slit2) and Roundabout receptors (Robo3) are also involved in the migration of GnRH neurons. Specifically, mice lacking Slit2 contained fewer GnRH neurons in the forebrain compared with wild-type controls, resulting in much reduced innervation of the median eminence [73,74]. Another glycoconjugate (glycosyltransferase $\beta 1,3 \mathrm{~N}$-acetylglucosaminyltransferase- 1 ( $\beta 3 \mathrm{GnT} 1$ ) helps synthesize lactosamine 
with maximum expression on ED13. Mice with disrupted expression of $\beta 3 \mathrm{GnT1}$ show GnRH neurons retained in the nasal area on ED15, fewer neurons in the forebrain and misdirection (those neurons are displaced in the dorsal rather than the ventral forebrain) [75]. Reelin is an extracellular glycoprotein and expressed by the vomeronasal neurons but not GnRH neurons. Reeler mice had a lower numbers of GnRH neurons in forebrain associated with further decreased fertility [76]. Reelin provides positional cues to radially migrating neurons in the cerebral cortex and plays a role in guiding the migration of $\mathrm{GnRH}$ neurons in the developing basal forebrain [76]. Netrins are a family of secreted proteins that are involved in the formation of many nerve tracts in the brain. The transmembrane protein DCC has been identified as a receptor for netrins. This protein is found in nerve fibers that express peripherin and serve as a guideway for $\mathrm{GnRH}$ neuron migration in the nasal head region [77]. The DCC mRNA has been detected in some GnRH neurons located in this region, but not in neurons that have already entered the forebrain [78].

Another chemoattractant protein playing such a role is the hepatocyte growth factor/scatter factor (HGF/SF), with c-Met tyrosine kinase receptors for this protein, being found in the immediate vicinity of migrating GnRH neurons [79]. It has been shown that the chemokine stromal cell-derived factor 1 (SDF-1) and one of its receptors, CXCR4, also participate in the intranasal migration of GnRH neurons [80,81]. SDF-1 appears to accelerate the speed of their movement via changes in potassium concentration inside the cells [16].

\subsection{Cytokines}

Cytokines, as a large and diverse family of regulators secreted by the glial cells of the nervous system and by numerous cells of the immune system, in particular, leukemia inhibitory factor (LIF), monocyte chemoattractant protein-1 (MCP-1), and interleukin (IL)-6, take part not only in GnRH secretion, but also in the development of olfactory structures and migration of GnRH neurons. During the period of intranasal migration of GnRH neurons to the brain, expression of these cytokines and their receptors is observed in this area $[37,82]$. Receptors for IL-6 were identified on the migration pathway GnRH neurons on the olfactory and vomeronasal nerves [37]. On the neuronal cells of the Gnv-4 line, which synthesize GnRH, receptors for the $\alpha$ chain of IL-6 are also expressed [60]. Using GN11 cells as a model of immature, migratory GnRH neurons, Magni et al. [83] showed that LIF induced their chemokinesis. MCP-1 and its receptor, chemokine (C-C motif) receptor-2 (CCR2), were found to be expressed in the hypothalamic GnRH neurons, as well as in GT1-7 and GN11 cell lines, with MCP-1 stimulating migration of these immature GnRH neurons [84].

Moreover, on the germ cells, including oocytes in primordial follicles, of human fetal ovaries receptors for IL- 6 and LIF were identified, and their expression was increased significantly with increasing gestation [85]. On the cells of the urogenital tract, receptors for LIF were also detected [86]. An increase in the level of LIF in the blood of a pregnant female rat after its exogenous administration is accompanied by an increase in the level of this cytokine in the blood and cerebrospinal fluid of fetuses [87] and an increase in the level of MCP-1 in the mother was accompanied by its increase in the brain of fetuses [41]. IL-6 can be transported from the mother through the placental barrier to the fetus [88].

IL-1 $\beta$ has been shown to reduce the spontaneous expression of $c-$ fos protein located within the nuclei of GnRH neurons in proestrus rats. The in vivo data demonstrate inhibition of GnRH, whereas in vitro studies demonstrated that IL-1 $\beta$ stimulates GnRH release [89].

\subsection{Neurotransmitters}

Neurotransmitters control the migration of GnRH neurons mainly at the stage of their entry into the forebrain. In mice, their migration is retarded at the cribriform plate, against the background of an increase in intracellular calcium resulting from GABA-induced tonic polarization of these cells $[16,90]$. This delay may be necessary for the maturation of $\mathrm{GnRH}$ 
neurons or reorganization of their behavior prior to entering the forebrain. GABA also has an effect on their distribution in the forebrain. Glutamate is another neurotransmitter influencing the migration of GnRH neurons, with its influence being different in the nasal head region and in the forebrain. In particular, treatment of pregnant mice with AMPA ( $\alpha$-amino-3-hydroxy-5-methyl-4-isoxazolepropionic acid) receptor blocker has proved to retard the entry of GnRH neurons into the forebrain in fetuses [91]. There have been shown that the spatiotemporal segregation of glutamic acid decarboxylase isoforms (GAD) defines distinct GABA signaling functions in the developing mouse olfactory system [92].

Monoamines also modulate the migration of GnRH neurons. As shown on the model of serotonin deficiency in rat fetuses, this monoamine stimulates their proliferation and further migration to the forebrain [13]. According to our data, suppression of catecholamine synthesis in rat embryos by $\alpha$-methyl-p-tyrosine ( $\alpha \mathrm{MPT}$, a competitive tyrosine hydroxylase inhibitor) beginning from ED11 leads to an increase in the number of GnRH neurons in the rostral segments of their migration route by ED17 and their accumulation in the zone of their entry into the forebrain by days 18-21 [93]. In addition to GnRH, monoamines also affect the thymic development and functioning of the immune system [94,95].

\subsection{Transcription Factors}

The initial stages of the differentiation of olfactory placodes and the precursors of GnRH neurons are controlled by transcription factors (Table 1).

Table 1. The most general transcriptional factors participating in organization of GnRH neuron development and its migratory route formation.

\begin{tabular}{|c|c|c|c|}
\hline Transcriptional Factor & General Action & Action on GnRH & References \\
\hline Pax-6,7 & $\begin{array}{l}\text { The role of Pax- } 6 \text { in } \\
\text { eye and nasal } \\
\text { development }\end{array}$ & $\begin{array}{l}\text { Its expression appears in the } \\
\text { olfactory ensheathing cells and } \\
\text { vomeronasal organ. PAX6 and } \\
\text { AP-2 define distinct progenitor } \\
\text { cells mixed within the } \\
\text { developing nasal placode }\end{array}$ & {$[96,97]$} \\
\hline Eya-1,2 & $\begin{array}{l}\text { The role in } \\
\text { developmental } \\
\text { process conserved } \\
\text { across vertebrates }\end{array}$ & $\begin{array}{l}\text { It is initially expressed in a row } \\
\text { of eight cells located } \\
\text { immediately anterior to the } \\
\text { neural plate }\end{array}$ & {$[98,99]$} \\
\hline Six-1,3,6 & $\begin{array}{l}\text { Six is restricted to the } \\
\text { developing eye and } \\
\text { brain }\end{array}$ & $\begin{array}{l}\text { Mice lacking Six1 (Six } 1-/- \text { ) } \\
\text { exhibited defective early } \\
\text { neurogenesis in the } \\
\text { olfactory epithelium. } \\
\text { Loss of Six6 expression } \\
\text { disrupts male fertility because } \\
\text { of decreased } \\
\text { follicle-stimulating } \\
\text { hormone release }\end{array}$ & [99-101] \\
\hline OTX-1,2 & $\begin{array}{l}\text { Involvement in the } \\
\text { early development } \\
\text { of CNS }\end{array}$ & $\begin{array}{l}\text { The role in the initiation and } \\
\text { guidance of directed migration. } \\
\text { In mice with deletion of the } \\
\text { transcription factor Otx } 2 \text { found } \\
\text { fewer GnRH neurons }\end{array}$ & {$[102,103]$} \\
\hline Gli3 & $\begin{array}{l}\text { It is necessary for the } \\
\text { development of } \\
\text { olfactory system }\end{array}$ & $\begin{array}{c}\text { Regulates vomeronasal } \\
\text { neurogenesis, olfactory } \\
\text { ensheathing cell formation and } \\
\text { GnRH neuronal migration }\end{array}$ & {$[104,105]$} \\
\hline
\end{tabular}


Table 1. Cont.

\begin{tabular}{|c|c|c|c|}
\hline Transcriptional Factor & General Action & Action on GnRH & References \\
\hline Ebf2 & $\begin{array}{l}\text { Involvement in } \\
\text { numerous } \\
\text { developmental } \\
\text { processes, ranging } \\
\text { from B-cell } \\
\text { development to } \\
\text { neuronal } \\
\text { differentiation }\end{array}$ & $\begin{array}{l}\text { It is expressed in migrating } \\
\text { GnRH neurons on embryonic } \\
\text { day } 11 \text { (ED11). Mice with } \\
\text { disrupted expression of Ebf2 } \\
\text { retained GnRH neurons } \\
\text { clustered in the } \\
\text { nasal mesenchyme }\end{array}$ & {$[106,107]$} \\
\hline Nhlh2 & $\begin{array}{l}\text { Its expression in } \\
\text { regions of the } \\
\text { hypothalamus as well } \\
\text { as the pituitary }\end{array}$ & $\begin{array}{l}\text { Mice with disrupted } \\
\text { expression of Nhlh2 had a loss } \\
\text { of GnRH neurons in adulthood } \\
\text { that occurred sometime } \\
\text { between birth and adulthood } \\
\text { (loss of } 60 \% \text { in females and } 30 \% \\
\text { in males) }\end{array}$ & {$[108,109]$} \\
\hline VAX1 & $\begin{array}{l}\text { It is essential for the } \\
\text { formation of the eye, } \\
\text { ventral forebrain } \\
\text { and palate }\end{array}$ & $\begin{array}{l}\text { GnRH staining in Vax1null } \\
\text { mice show a total absence of } \\
\text { GnRH expression in the adult. } \\
\text { Using the immortalized model } \\
\text { GnRH neuron cell lines, GN11 } \\
\text { and GT1-7, it was show that } \\
\text { VAX1 is a direct regulator of } \\
\text { GnRH transcription by binding } \\
\text { key ATTA sites within the } \\
\text { GnRH promoter. }\end{array}$ & {$[110,111]$} \\
\hline $\begin{array}{l}\text { Mash-1, Math4A, } \\
\text { Math4/neurogenin1, } \\
\text { NeuroD }\end{array}$ & $\begin{array}{l}\text { Involvement in } \\
\text { gliogenesis and } \\
\text { neurogenesis }\end{array}$ & $\begin{array}{l}\text { Differentiation into the } \\
\text { olfactory epithelium }\end{array}$ & {$[101,112]$} \\
\hline Olf-1, GATA-4 & $\begin{array}{l}\text { Involvement in brain } \\
\text { development }\end{array}$ & $\begin{array}{l}\text { Its expression in the } \\
\text { olfactory epithelium } \\
\text { Its expression is necessary for } \\
\text { GnRH pulse activity }\end{array}$ & {$[113,114]$} \\
\hline $\mathrm{AP}-2 \alpha$ & $\begin{array}{l}\text { Involvement in } \\
\text { craniofacial } \\
\text { morphogenesis }\end{array}$ & $\begin{array}{l}\text { Its expression only in the } \\
\text { respiratory epithelium. It } \\
\text { prevents recapitulation of } \\
\text { developmental programs } \\
\text { within the respiratory } \\
\text { epithelium that lead to } \\
\text { expression of GnRH and } \\
\text { peripherin phenotypes }\end{array}$ & [113] \\
\hline
\end{tabular}

\section{Development of the GnRH System in Different Pathological States}

Disorders in the development of the GnRH system lead to impaired puberty and fertility in adults. The reasons for the development of reproductive system disorders in most patients are still not fully determined. Genetic mutations in genes that determine the synthesis of factors involved in the migration of $\mathrm{GnRH}$ neurons are detected in no more than $50 \%$ of patients [115]. Despite the fact that the proportion of certain genetic causes of underdevelopment of the reproductive system is growing, adverse factors affecting the developing human body in early ontogenesis can significantly influence the development of the GnRH system $[37,50,116,117]$. The best known disease associated with impaired migration of GnRH neurons is the so-called Kallmann syndrome. The diagnosis of Kallmann syndrome is based on the identification of impairments in sexual development: a decrease in the mass of the gonads, as well as low secretion of gonadotropins and sex steroids, and in addition, these symptoms are accompanied by a loss of smell (anosmia). When there 
is Kallmann syndrome in a human fetus with a genetic mutation in the $\mathrm{X}$-linked gene $K A L 1$, there is a complete impairment of the penetration of GnRH neurons into the brain, with neurons located in the nasal region along the dorsal surface of the ethmoid plate of the ethmoid bone [118]. Receptor, which is activated by the prokineticins (PRKR2), and the mouse nasal embryonic GnRH factor gene (NELF) are required for olfactory axonal outgrowth and GnRH neuronal migration in mice [119].

Reproductive impairment caused by decreased GnRH secretion is not always associated with impaired neuronal migration. Abnormal development of the gonads without defects in the development of the olfactory system in humans is called idiopathic hypogonadotropic hypogonadism. This pathology is more common in men and manifests itself in the early postnatal period [120]. The absence of puberty against the background of a decrease in GnRH secretion was also found in women [120].

For studies of pathological processes developing in the reproductive system, hypogonadal mice (hpg mice) are widely used. These mice have a general underdevelopment of the gonads and disorders of the reproductive system. They have a spontaneous deletion mutation of 33.5 kilobases encompassing the distal half of the GNRH1 gene, which completely disrupts the transcription and synthesis of $\mathrm{GnRH}$, leading to a lifelong deficiency of gonadotropins and sex steroids. In male $h p g$ mice, changes in the concentration of amyloid precursors, as well as a decrease in the level of IL-1 $\beta$ in the hippocampus and choline acetyltransferase per neuron, were revealed, similar to changes in patients with Alzheimer's disease [121].

Currently, more and more clinical and experimental data are coming in on the negative influence of various unfavorable factors on the developing fetus, including the HPG axis. Their impact leads to persistent changes in the epigenetic regulation of gene transcription, and as a consequence, to phenotypic changes $[116,122,123]$. The HPG axis disorders are based on epigenetic modification of the estrogen receptor $(E R \alpha)$ gene promoter and subsequent changes in the expression of this gene $[124,125]$. It has been shown that estrogens increase the expression of the KISS1 gene in the brain of mice by the acetylation of histones in its promoter region in the anteroventral periventricular nucleus of the hypothalamus and suppress its expression by the deacetylation of histones in the arcuate nucleus. Epigenetic regulation of the KISS1 gene by estrogen-positive feedback induces the release of $\mathrm{GnRH}$ [126]. Suppression of KISS1 gene expression in female rats in the medial preoptic region of the hypothalamus, induced by systemic inflammation in the neonatal period, significantly slows down the onset of puberty [127].

One of the risk factors is a bacterial infection that induces inflammation in both the mother and the fetus $[37,47,50-52,128]$. Bacterial infections, particularly asymptomatic infections during pregnancy that are not normally treated, can lead to serious complications including pre-term parturition, low birth weight, and CNS damage [51,129-132].

Experimental studies often use LPS, a major component of the outer membrane in bacteria. LPS is a strong inducer of innate immunity consisting primarily of cytokine induction, inflammation, fever, complement cascade activation, hypothalamic-pituitary-adrenal (HPA) axis activation, and sickness behavior [47,51]. By inducing an immune response in the mother, LPS is able to alter the level of cytokines in the fetus. Proinflammatory cytokines are probably a link between maternal infection and subsequent disruptions in the development and further functioning of various brain systems in the offspring.

According to our data, activation of the immune system of rats or mice by LPS (Escherichia coli) on the 12th day of pregnancy leads to a decrease in the rate of migration of GnRH neurons from the nasal region to the brain and is accompanied by an increase in the level of IL-6, LIF, and MCP-1 in the blood of the mother and the fetuses [37,117]. In sexually mature offspring, there is a decrease in the level of $\mathrm{GnRH}$ in the hypothalamus and a reduction in the level of gonadotropins and sex steroids in the peripheral blood [50]. The effect of immunological stress on the development of the fetal $\mathrm{GnRH}$ system depends on the period of exposure. If such activation takes place at the initial stage of $\mathrm{GnRH}$ neuronal migration in the fetus, it results in the overall disorganization of this process. At the same 
time, LPS administration to pregnant females at subsequent stages of neuronal migration does not lead to a redistribution of GnRH neurons in the fetal brain, which indicates that some other mechanisms become involved in the regulation of their migration [37].

The appearance of GnRH neurons in the forebrain with a delay, apparently, causes changes in the formation of the necessary axonal connections, which leads to impairments at key points in the development of the HPG axis. In adult animals, LPS-induced inflammation has been proposed to suppress axonal transport of GnRH mRNA to GnRH neurons in the preoptic region and the median eminence of the hypothalamus, where their terminals are projected and GnRH mRNA is detected [133]. The formation of a synaptic network that modulates the function of GnRH neurons is controlled by the integrative activity of internal and external signals. Thus, suppression of GnRH synthesis in the hypothalamus and suppression of gonadotropin secretion in the pituitary gland after systemic administration of LPS to rats are accompanied by an increase in IL-1 $\beta$ secretion and tumor necrosis factor (TNF) $\alpha$ in the medial preoptic region of the hypothalamus [134]. It is known that an increased level of TNF $\alpha$ in the blood induces sepsis and in the brain, it causes apoptosis of developing oligodendrocytes, mediated by the apoptosis-inducing factor (AIF), which is translocated into the nucleus under the influence of TNF $\alpha[135,136]$. An LPS-induced intrauterine inflammation in mice, accompanied by increased levels of TNF $\alpha$, leads to hypomyelination and diffuse brain damage, both in the white matter and in the gray matter of fetuses, including the hypothalamus, the thalamus, and the hippocampus [42,137].

With the central administration of IL- $1 \beta$, an increase in the levels of $\beta$-endorphin and tachykinins is observed. They are involved in the retransmission of the cytokine signal into GnRH neurons and suppress their functioning [138]. IL-1 $\alpha$ and granulocyte macrophage colony-stimulating factor (GM-CSF) block NO-induced GnRH secretion in the mediobasal region of the hypothalamus, which in turn blocks the pulsatile secretion of LH into the blood and suppresses GnRH-regulated sexual behavior [59]. Through GnRH neurons, various neurotransmitters and neuropeptides, such as monoamines, GABA, neuropeptide Y, opioids, cytokines, KISS1, as well as leptin, transmit external stimulus signals that affect the state of the HPG system $[2,18,23,82,92,133]$.

An LPS-induced inflammation in the mother during pregnancy causes impairments in the formation of GABA-, dopamine- and serotonin-producing neurons in the developing fetal brain $[43,132]$. Administration of LPS to female rats on the 11th day of gestation leads to a decrease in the number of dopaminergic neurons and an increase in the activity of microglia, as well as to an increase in the level of proinflammatory cytokines, mainly $\mathrm{TNF} \alpha$, in the substantia nigra in postnatal offspring [43]. Moreover, LPS can influence the differentiation of monoaminergic neurons not only in the brain stem, but also in other brain structures, including the hypothalamus in fetuses. After the introduction of LPS, the following was observed: a decrease in the expression of the enzyme synthesizing dopamine (tyrosine hydroxylase) in the substantia nigra and of the enzyme synthesizing serotonin (tryptophan hydroxylase) in the dorsal raphe nucleus, a decrease in the levels of dopamine and serotonin in the olfactory bulbs of the frontal cortex, the nucleus accumbens, the striatum, the amygdala, the hippocampus, and the hypothalamus, as well as a decrease in the expression of the enzyme synthesizing GABA and reelin in the dentate gyrus and the CA1 in offspring $[43,139,140]$.

Thus, activation of the immune system in early ontogenesis triggers a cascade of intermediators that cause impairments in the formation of both the immune system and the HPG system, which leads to an increased risk of immunological, behavioral, and reproductive disorders in offspring.

\section{Effects of GnRH on the Development and Functioning of the Immune System}

$\mathrm{GnRH}$ is an important signaling molecule in neuroendocrine-immune interactions $[2,141]$. Hypothalamic and extracerebral GnRHs are involved in the regulation of the development and functioning of the immune system at different stages of ontogenesis. At the same time, the level of $\mathrm{GnRH}$ in the general circulation in adults is low, while in fetuses its level 
is much higher than that in postnatal life [11,12]. After removal of the hypothalamus by in utero encephalectomy in 18-day-old rat fetuses, the level of GnRH in the thymus and peripheral blood of 21-day-old fetuses of both sexes is halved compared to the norm [11]. Since in the prenatal period of development, the blood-brain barrier in mammals is just beginning to form and is poorly functioning, at least half of the GnRH enters the periphery from the fetal brain.

According to current conceptions, hormones that control certain functions in adults act on the formation of these functions in perinatal ontogenesis $[9,10,142]$. They control the growth and differentiation of various fetal tissues, including lymphoid tissue. Changes in the physiological concentrations of hormones, including $\mathrm{GnRH}$, as well as the effects of various unfavorable environmental factors on the developing fetus, cause impairments in the programming of the regulatory mechanisms of the neuroendocrine and immune systems [143]. As a result, disorders occur in the immune system, primarily in the development of the central organs (the thymus and bone marrow), which subsequently leads to impairments in the functioning of peripheral lymphoid organs (the spleen and lymph nodes) [6].

GnRH is involved in the regulation of the development and functioning of thymic $\mathrm{T}$ lymphocytes already in prenatal ontogenesis. Central and peripheral blockade of GnRHRs by a selective antagonist or specific antibodies in rat fetuses leads to suppression of the mitogen-induced proliferative response of fetal thymocytes, while administration of $\mathrm{GnRH}$ completely restores the immune response to normal $[11,144]$. In utero blockade of GnRHRs at the peak of their expression in the thymus of rats on ED17 by the antagonist causes suppression of the mitogen-induced proliferative response of T-lymphocytes not only in fetuses, but also in mature offspring. After the administration of the GnRH antagonist to sexually mature rats, the impairments in the development of the cellular immune response were short-lived and reversible [6]. Blockade of GnRHRs by an antagonist in rats for five neonatal days subsequently leads to suppression of the humoral and cellular immune response [28], at the same time, a single administration of the antagonist to rat pups on the 3rd day after birth does not affect the functional activity of thymocytes in adults [6]. After neonatal chronic exposure to the antagonist, a decrease in the mass of the thymus and the number of mature T- and B-lymphocytes in lymphoid organs and peripheral blood was observed in sexually mature rats and primates [145]. Differences in the effects of GnRH on the immune system at different periods of ontogenesis may be associated with the involvement of different regulatory mechanisms. In rat fetuses, hypothalamic control of gonadotropin secretion by the pituitary gland is formed on ED21. At the same time, axonal pathways of GnRH transport to the portal circulation are formed and expression of GnRHR on gonadotropocytes begins, which is most pronounced by 10-12 days after birth [12,146]. The high level of GnRHR expression on ED17-18, as well as the absence of long-term consequences of a single administration of the GnRH antagonist at the very beginning of the neonatal period, indicates the regulatory effect of $\mathrm{GnRH}$ on thymocyte formation at the end of the second decade of intrauterine development. With chronic exposure to the antagonist in the neonatal period, the effects of GnRH are probably realized through gonadotropins. The schematic representation of GnRH effects on the thymus development in fetal rats is presented on Figure 3. 


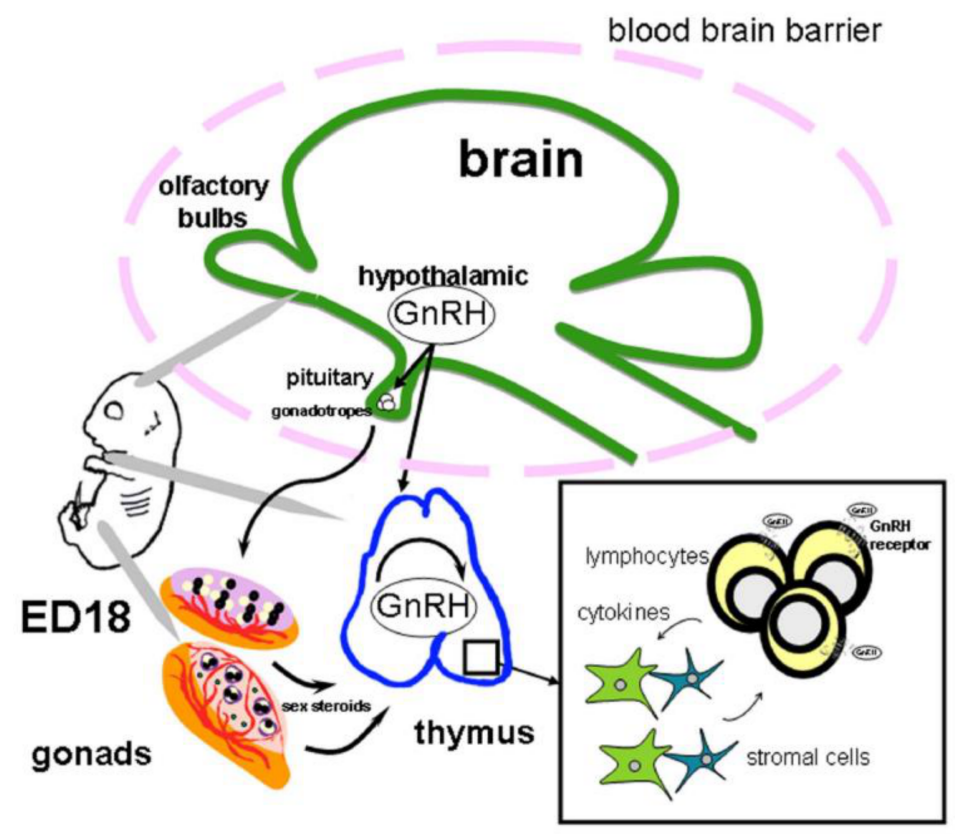

Figure 3. Model of the gonadotropin-releasing hormone $(\mathrm{GnRH})$ regulation in the thymus during ontogeny. During prenatal development, before the establishment of the hypothalamic-pituitarygonadal regulation in rodents, hypothalamic $\mathrm{GnRH}$ is found in the general blood circulation in high concentrations and can provide a direct effect on the morphogenesis of thymus via specific receptor in thymocytes. In addition, the effect of GnRH synthesized in thymus can be realized by autocrine or paracrine regulation. During early development, the effect of GnRH is mediated by cytokines whose synthesis in the thymus is upregulated by this neuropeptide. During the postnatal period, GnRH is involved in the bidirectional programming of the both neuroendocrine and immune functions via gonadotropins and sex steroids. Sex steroids modulate the GnRH level in the thymus. Abbreviation: ED-embryonic day.

In the prepubertal period, GnRH modulates the development of hematopoietic stem cells in the central organs of the immune system. Two to three weeks after treating female mice during this period with a long-acting analog of GnRH lupron depot (prepared as a long-term slow release formulation), the number of T-lymphocytes in the thymus and B-lymphocytes in the bone marrow is significantly reduced. This leads to a decrease in their number and suppression of cellular immunity in the peripheral lymphoid organs [147]. GnRH and its agonists prevent cell apoptosis [148], normalize the number of T-lymphocytes in the thymus, mainly CD4 T helper cells, and their functional activity, both in pre- and postpubertal periods $[6,149]$.

The mechanisms of GnRH action on the immune system are not fully understood, and they seem to be different at different stages of ontogenesis. One of the possible mechanisms for regulating the number of lymphocytes is the ability of GnRH to induce the expression of cytokines and their receptors. It is known that cytokines are involved in the processes of proliferation and differentiation of lymphocytes, in the regulation of cell-cell interactions, apoptosis, and morphogenesis [150,151]. Moreover, in different periods of ontogenesis, they have different effects. In adults, cytokines are involved in the regulation of the immune response to various foreign antigens, while in early development they model the processes of formation of various organs and tissues of the fetus, including brain structures $[87,152]$.

In the postnatal period of life, GnRH enhances the expression of the IL-2 receptor $(\mathrm{IL}-2 \mathrm{R} \gamma$ ) on T-lymphocytes: this receptor triggers an IL-2 dependent mitogen-induced proliferative response [153,154]. In culture of B-lymphoblastoid cells, GnRH also enhances their proliferative activity, which is most pronounced in the presence of IL-2 [155].

In prenatal ontogenesis, GnRH in physiological concentrations does not induce the synthesis of IL-2 in the fetal thymus, while the synthesis of IL-4, IL-10, TNF $\alpha$ and interferon 
(IFN) $\gamma$ increases. GnRH has the greatest effect on the synthesis of the lymphocyte differentiation factor IL-4, which, as is known, in synergy with IL-10, regulates the synthesis of other cytokines $[6,156]$. The GnRH antagonist suppresses the expression of IL-4, IFN $\gamma$, IL-1 $\beta$, and TNF $\alpha$, while IL-1 $\alpha$, IL-2, and IL-10 remain unchanged. It was shown that in the fetal thymus of mice, the synthesis of IL- $1 \beta$, IL- 4 , IL-5, IL-6, IL-7, IFN $\gamma$, and TNF $\beta$ begins from ED14, while that of IL-1 $\alpha$, IL-2, and IL-3 starts from embryonic day 16 [156]. At the same time, the synthesis of IL-7, which stimulates the proliferation, but not the differentiation of T-lymphocytes, slows down by the time of the synthesis of IL-2, which indicates the involvement of certain cytokines at certain stages of thymus development. Thus, in prenatal ontogenesis, GnRH is probably, like many hormones and mediators, an inducer of development, exerting a morphogenetic effect conditioned by cytokines on the central organs of the immune system, in particular the thymus.

Sex steroids, and first of all testosterone, the synthesis of which by Leydig cells in rat fetuses was detected already on ED 18-19 [157], modulate the molecular processing of the GnRH precursor and, therefore, the GnRH level in the hypothalamus and thymus [158]. In the thymus of castrated 2-month-old male rats, the level of the GnRH precursor decreases, while the GnRH level increases in the thymus and decreases in the hypothalamus. Testosterone replacement therapy prevents these effects [158]. At the same time, the level of GnRH mRNA in castrated rats does not change, which indicates the post-translational effect of testosterone, which suppresses GnRH processing. Since in non-castrated males the concentration of GnRH in the thymus was lower than in the hypothalamus, while the level of the precursor of GnRH in the thymus was much higher, the authors suggested that the regulation of molecular processing by testosterone in these tissues occurs in different ways.

According to Jacobson and Ansari (2004) [159], the stimulating effects of estrogens and the suppressive effects of androgens on the number and functioning of B-lymphocytes are realized only in the presence of GnRH. Along with the modulation of the immune response, the participation of GnRH and sex steroids in autoimmune processes is assumed $[35,160]$. After treating systemic lupus erythematosus-prone male and female mice, who were $F_{1}$ hybrid (SWR $\times$ NZB), with GnRH antagonist, a decrease in the total levels of immunoglobulin (IgG) and anti-DNA antibodies, a decrease in the severity of clinical manifestations of the disease, and an increase in life expectancy were observed in both sexes. At the same time, after the introduction of the GnRH agonist (native decapeptide) or its analogs, exacerbation of the disease was observed in females, but not in males [160]. The observed effects in the course of autoimmune diseases, as suggested by the authors, may be due to sex differences in the expression of GnRHR or G proteins. After 2 weeks of treating mice with systemic lupus erythematosus with $\mathrm{GnRH}$, the expression of GnRHR and the binding of its ligand in the spleen of ovariectomized but not castrated animals are suppressed. At the same time, an increase in the expression of IL-2 and its receptor is observed in females. GnRH realizes its effects through a $G$ protein-coupled receptor, specifically through two highly homologous $\mathrm{G}$ proteins $\mathrm{G} \alpha \mathrm{q}$ and $\mathrm{G} \alpha_{11}\left(\mathrm{Gaq} /{ }_{11}\right)$. It turned out that in the spleen of females, the expression of Gaq/11 is more pronounced than in males, and their expression is enhanced by GnRH in both intact and ovariectomized mice [161].

Thus, GnRH can control the formation and functioning of the immune system through the HPG axis, as well as carry out autocrine or paracrine regulation of the immune response. At the same time, adverse effects in the perinatal period, as a rule, might cause irreversible or long-term current structural and functional disorders, while in puberty, these disorders are short-lived and reversible.

\section{Approaches to Preventing or Reversing Disorders Induced by Acute Inflammation in Early Ontogenesis}

The increase in the number of couples of childbearing age suffering from infertility is becoming a serious problem for men and women and constitutes $8-15 \%$ worldwide. Genetic, physiological, social, and environmental factors contribute to the development of infertility, especially when exposed to them during critical periods of the formation of the HPG axis. In infertile men, various viruses are often detected in the semen and tissues 
of the reproductive tract [1]. A low sperm count is found in 15-20\% of young men [162]. In women, asymptomatic diseases caused by gram-negative bacteria are common [163], which is especially dangerous during gestation. The consequences of negative effects on the fetus are not always traced; therefore, the therapy carried out at puberty, as a rule, does not allow the elimination of the identified fertility disorders.

Currently, data are accumulating on the possibility of preventing or reversing the short-term and long-term consequences of intrauterine inflammation. An effective neuroprotective agent for the fetus is magnesium sulfate $(\mathrm{Mg})$, which is prescribed to women at risk of preterm birth [164]. Experimental studies have shown that $\mathrm{Mg}$ administered to female rats on ED16 before LPS injection significantly decreases brain neuronal nitric oxide synthase, nuclear factor NF- $\mathrm{KB}$, and chemokine (C-C motif) ligand 2 protein, the levels of which increase after exposure to LPS. The Mg effect was mediated through the $\mathrm{N}$-methyl-D-aspartate receptor (NMDAR). In addition, $\mathrm{Mg}$ reduced the increased levels of $\mathrm{NO}$ and proinflammatory cytokines in the fetal brain [165].

Antioxidant $\mathrm{N}$-acetyl-cysteine (NAC) also prevents the rat fetal brain from inflammatory cytokine responses to LPS [166]. Suppression of the synthesis of TNF $\alpha$, IL-6, and IL-10, as well as suppression of the development of local inflammation in the fetal brain, led to the reversal of the long-term negative consequences of inflammation [137]. In an in vitro model, it has been demonstrated that NAC inhibits an NF- $\mathrm{kB}$ activated pathway and subsequent phospholipid metabolism, proinflammatory cytokine release, and protease activity in human fetal membranes [167].

Studies of pregnant women with Zn deficiency have shown that they have increased risks of low birth weight and small for gestational age infants. At the same time, the levels of C-reactive protein, TNF $\alpha$, and IL-8 in maternal serum, as well as the concentration of the nuclear factor NF- $\mathrm{kB}$ p65, significantly exceed the normal level [168]. According to Chua et al. (2012) [169], activation of the maternal immune system by LPS in mid- and late pregnancy induces the production of metallothionein, which redistributes $\mathrm{Zn}$ in the mother, limiting its entry into the fetus. Zn deficiency in the fetus leads to damage in development of the nervous system. Zn co-administered with LPS to mice on ED16 prevents astrogliosis, brain cell death, and increased TNF $\alpha$ synthesis.

Protective anti-inflammatory properties have also been found in polyunsaturated fatty acids ("n-3 PUFAs", known as omega-3) [170] and vitamin D [171]. The intake of vitamin $\mathrm{D}$ by pregnant women results in an increase in the weight and height of the newborn [172] It is known that the quality, quantity, and timing of food consumption during pregnancy affect the growth and development of the fetus [173]. Newborns with low birth weight, caused by improper nutrition of the mother, have an increased risk of mortality from congenital heart disease and are more likely to suffer from the development of metabolic syndromes, obstructive pulmonary diseases, renal failure, allergic diseases, as well as reproductive dysfunction in young offspring. The developing fetus is most sensitive to substances such as amino acids and folic acid (B9), as well as vitamins B6 (pyridoxine) and B12 [174]. Their increased levels in early ontogenesis can reprogram the development of systems, and therefore, the use of various additives, including vitamins, during pregnancy should be treated with caution.

We have demonstrated the possibility of reversing the structural and functional disorders of the HPG system in male and female rats induced by prenatal exposure to LPS. In the prepubertal period, males showed increased levels of estradiol, while females showed increased levels of testosterone. Antagonists of sex steroids, introduced during this period, normalized inflammation-induced disorders [51,52].

In recent years, fundamentally new anti-inflammatory "genetically engineered biological drugs" have been created, the use of which has made it possible to significantly increase the effectiveness of pharmacotherapy. These include monoclonal antibodies against certain determinants of immune cells or proinflammatory cytokines, as well as hybrid protein molecules that inhibit the activity of cytokines or the interaction of T- and B-lymphocytes. Tocilizumab (TCZ), which is clinically used mainly for the treatment of arthritis, may be 
a promising corrective drug that suppresses inflammation in the early stages of development [175]. TCZ is a recombinant humanized anti-IL-6 receptor monoclonal antibody of the $\operatorname{IgG1} 1_{\mathrm{k}}$ subclass [176]. IL-6 is a key marker of neuroinflammation and lethal sepsis following bacterial or viral activation of the immune system. It has been proven experimentally that an increase in the level of IL-6 in female mice in early pregnancy causes behavioral and transcriptional changes in the brain of adult offspring. Antibodies against IL-6 (IgG1), administered to pregnant mice immediately after their activation by double-stranded RNA (poly (I:C)), normalize the induced changes in the adult offspring [177].

Attempts are being made to neutralize increased levels of proinflammatory cytokines by an intravenous administration of human IgG (IVIG) [178-180]. In experimental rodent models with LPS-induced endotoxemia, IgG and IgM suppressed increased cytokine synthesis and the development of immunosuppression [181]. According to our preliminary data, IgG administered intravenously to pregnant female mice 40 min after LPS administration reverses, although not completely, structural abnormalities of the gonads in male offspring.

The mechanism of action of Ig during bacterial infection is not yet fully understood. It is assumed that Ig binds to Fc- $\gamma$ receptors on macrophages [182], decreasing their sensitivity to signals through Toll receptors, and therefore to LPS, which leads to a decrease in the synthesis of proinflammatory cytokines and protection from LPS-induced death in animals $[178,183,184]$. Ig is able to enhance the expression of negative regulators of LPSinduced NF-kB signaling. IgG induces the activation of JNK (Jun kinase) and the synthesis of the signal peptide activin A in anti-inflammatory macrophages, causing their generation, as well as inhibiting the granulocyte-macrophage colony-stimulating factor (GM-CSF)initiated activation of the transcription factor STAT5 (signal transducer and activator of transcription-5), limiting the differentiation of proinflammatory macrophages [178]. Moreover, activin A makes a significant contribution to the effects of IgG. An increase in the level of activin A in the blood after IVIg administration contributes to the beneficial effect of Ig on women with recurrent reproductive failure.

To preserve reproductive health at childbearing age in men and women, we focus on the possibility of correcting the effects of bacterial infection in the mother in early pregnancy (first trimester in humans). Two critical periods can be defined: 1 . in the prenatal period, the administration of IgG or antibodies to proinflammatory cytokines at the initial stages of their synthesis; 2 . in the neonatal and early infantile periods, the administration of sex steroid antagonists, if there are elevated levels of sex steroids in the blood [47].

\section{Conclusions}

An analysis of existing research and our own data have shown that the regulation of the formation and functioning of the HPG and immune systems in a developing fetus is carried out with a close interaction of these systems. Epigenetic mechanisms are implemented during perinatal ontogenesis that ensures the adaptive plasticity of the physiological systems. Impairments in the molecular mechanisms of regulation in critical periods of development can cause long-term or irreversible changes in the functioning of the HPG and immune systems. Their reprogramming with various stressful stimuli during this period can lead to the emergence of metabolic, immunological, and reproductive disorders in the offspring. However, regulatory epigenetic mechanisms of development are not strictly genetically controlled. These processes are characterized by a high sensitivity to various regulatory factors, which makes it possible to correct disorders.

Funding: This research was funded by Ministry of science and higher education of Russian Federation, project number 075-15-2020-773.

Institutional Review Board Statement: All manipulations with animals were performed in accordance with the European Convention on the Protection of Vertebrate Animals Used for Experimental and Other Scientific Purposes (Strasburg, 1986) and approved by the Ethics Committee for Animal Research of the Koltzov Institute of Developmental Biology (Russian Academy of Sciences approval code: 23, approved on 15 November 2018).).

Informed Consent Statement: Not applicable. 
Conflicts of Interest: The authors declare no conflict of interest.

$\begin{array}{ll}\text { Abbreviations } \\ \text { CNS } & \text { Central nervous system } \\ \text { ED } & \text { Embryonic day } \\ \text { ER } \alpha & \text { Estrogen receptor alfa } \\ \text { FSH } & \text { Follicle-stimulating hormone } \\ \text { GABA } & \text { Gamma-aminobutyric acid } \\ \text { GM-CSF } & \text { Granulocyte macrophage colony-stimulating factor } \\ \text { GnRH } & \text { Gonadotropin-releasing hormone } \\ \text { HGF/SF } & \text { Hepatocyte growth factor/scatter factor } \\ \text { HPG } & \text { Hypothalamic-pituitary-gonadal (system) } \\ \text { IFN } \gamma & \text { Interferon gamma } \\ \text { IgG } & \text { Immunoglobulin G } \\ \text { IL } & \text { Interleukin } \\ \text { KISS1 } & \text { Kisspeptin } \\ \text { LH } & \text { Luteinizing hormone } \\ \text { LIF } & \text { Leukemia inhibitory factor } \\ \text { LPS } & \text { Lipopolysaccharide } \\ \text { MCP-1 } & \text { Monocyte chemoattractant protein-1 } \\ \text { SDF-1 } & \text { Stromal cell-derived factor } 1 \text { and one of its receptors CXCR4 } \\ \text { SEMA } & \text { Semaphorin } \\ \text { TNF } & \text { Tumor necrosis factor (alpha and beta) }\end{array}$

\section{References}

1. Tomaszewska-Zaremba, D.; Herman, A. The role of immunological system in the regulation of gonadoliberin and gonadotropin secretion. Reprod. Biol. 2009, 9, 11-23. [CrossRef]

2. Zakharova, L.A.; Izvolskaia, M.S. Interactions between the reproductive and immune systems during ontogenesis: The role of GnRH, sex steroids and immunomediators. In Sex Steroids; Kahn, S.M., Ed.; InTech: Rijeka, Croatia; London, UK, $2012 ;$ pp. $341-370$.

3. Quintanar, J.L.; Guzmán-Soto, I. Hypothalamic neurohormones and immune responses. Front. Integr. Neurosci. 2013, 7, 56. [CrossRef] [PubMed]

4. Segner, H.; Verburg-van Kemenade, B.M.L.; Chadzinska, M. The immunomodulatory role of the hypothalamus-pituitary-gonad axis: Proximate mechanism for reproduction-immune trade offs? Dev. Comp. Immunol. 2017, 66, 43-60. [CrossRef] [PubMed]

5. Stamatiades, G.A.; Kaiser, U.B. Gonadotropin regulation by pulsatile GnRH: Signaling and gene expression. Mol Cell Endocrinol. 2018, 463, 131-141. [CrossRef]

6. Melnikova, V.I.; Lifantseva, N.V.; Voronova, S.N.; Zakharova, L.A. Gonadotropin-Releasing Hormone in regulation of thymic development in rats: Profile of thymic cytokines. Int. J. Mol. Sci. 2019, 20, 4033. [CrossRef]

7. Han, X.; Ren, X.; Zeng, Y.; Zhou, Y.; Song, T.; Cao, X.; Du, X.; Meng, F.; Tan, Y.; Liu, Y.; et al. Physiological interactions between the hypothalamic-pituitary-gonadal axis and spleen in rams actively immunized against GnRH. Int. Immunopharmacol. 2016, 38, 275-283. [CrossRef]

8. Clarkson, J.; Han, S.Y.; Piet, R.; McLennan, T.; Kane, G.M.; Ng, J.; Porteous, R.W.; Kim, J.S.; Colledge, W.H.; Iremonger, K.J.; et al. Definition of the hypothalamic GnRH pulse generator in mice. Proc. Natl. Acad. Sci. USA 2017, 114, E10216-E10223. [CrossRef]

9. Zakharova, L.A. Plasticity of neuroendocrine-immune interactions during ontogeny: Role of perinatal programming in pathogenesis of inflammation and stress-related diseases in adults. Recent Pat. Endocr. Metab. Immune Drug Discov. 2009, 3, 11-27. [CrossRef]

10. Fowden, A.L.; Forhead, A.J. Endocrine mechanisms of intrauterine programming. Reproduction 2004, 127, 515-526. [CrossRef]

11. Zakharova, L.A.; Ermilova, I.Y.; Melnikova, V.I.; Malyukova, I.V.; Adamskaya, E.I. Hypothalamic control of the cell-mediated immunity and of the Luteinizing Hormone Releasing Hormone level in thymus and peripheral blood of rat fetuses. Neuroimmunomodulation 2005, 12, 85-91. [CrossRef]

12. Ugrumov, M.V.; Sapronova, A.Y.; Melnikova, V.I.; Proshlyakova, E.V.; Adamskaya, E.I.; Lavrentieva, A.V.; Nasirova, D.I.; Babichev, V.N. Brain is an important source of GnRH in general circulation in the rat during prenatal and early postnatal ontogenesis. Comp. Biochem. Physiol. A Mol. Integr. Physiol. 2005, 141, 271-279. [CrossRef] [PubMed]

13. Pronina, T.; Ugrumov, M.; Calas, A.; Seif, I.; Tramu, G. Influence of monoamines on differentiating gonadotropin-releasing hormone neurones in foetal mice. J. Neuroendocrinol. 2003, 15, 925-932. [CrossRef] [PubMed]

14. Giacobini, P.; Messina, A.; Morello, F.; Ferraris, N.; Corso, S.; Penachioni, J.; Giordano, S.; Tamagnone, L.; Fasolo, A. Semaphorin $4 \mathrm{D}$ regulates gonadotropin hormone-releasing hormone-1 neuronal migration through PlexinB1-Met complex. J. Cell Biol. 2008, 183, 555-566. [CrossRef] [PubMed]

15. Oleari, R.; Lettieri, A.; Paganoni, A.; Zanieri, L.; Cariboni, A. Semaphorin signaling in GnRH neurons: From development to disease. Neuroendocrinology 2019, 109, 193-199. [CrossRef] 
16. Casoni, F.; Hutchins, B.I.; Donohue, D.; Fornaro, M.; Condie, B.G.; Wray, S. SDF and GABA interact to regulate axophilic migraton of GnRH neurons. J. Cell. Sci. 2012, 25, 5015-5025. [CrossRef]

17. Herbison, A.E. The Gonadotropin-Releasing Hormone pulse generator. Endocrinology 2018, 159, 3723-3736. [CrossRef]

18. Uenoyama, Y.; Inoue, N.; Kei-Maeda, I.; Tsukamura, H. The roles of kisspeptin in the mechanism underlying reproductive functions in mammals. J. Reprod. Dev. 2018, 64, 469-476. [CrossRef]

19. Tena-Sempere, M. GPR54 and kisspeptin in reproduction. Hum. Reprod. Update 2006, 12, 631-639. [CrossRef]

20. Dhillo, W.S.; Murphy, K.G.; Bloom, S.R. The neuroendocrine physiology of kisspeptin in the human. Rev. Endocrinol. Metab. Disord. 2007, 8, 41-46. [CrossRef]

21. Han, X.; Zhou, Y.; Zeng, Y.; Sui, F.; Liu, Y.; Tan, Y.; Cao, X.; Du, X.; Meng, F.; Zeng, X. Effects of active immunization against GnRH versus surgical castration on hypothalamic-pituitary function in boars. Theriogenology 2017, 97, 89-97. [CrossRef]

22. Wakabayashi, Y.; Yamamura, T.; Sakamoto, K.; Mori, Y.; Okamura, H. Electrophysiological and Morphological Evidence for Synchronized GnRH Pulse Generator Activity among Kisspeptin/neurokinin B/dynorphin A (KNDy) Neurons in Goats. J. Reprod. Dev. 2013, 59, 40-48. [CrossRef] [PubMed]

23. Comninos, A.N.; Anastasovska, J.; Sahuri-Arisoylu, M.; Li, X.; Li, S.; Hu, M.; Jayasena, C.N.; Ghatei, M.A.; Bloom, S.R.; Matthews, P.M.; et al. Kisspeptin signaling in the amygdala modulates reproductive hormone secretion. Brain Struct. Funct. 2016, 221, 2035-2047. [CrossRef] [PubMed]

24. Hrabovszky, E.; Ciofi, P.; Vida, B.; Horvath, M.; Keller, E.; Caraty, A.; Bloom, S.; Ghatei, M.; Dhillo, W.; Liposits, Z.; et al. The kisspeptin system of the human hypothalamus: Sexual dimorphism and relationship with gonadotropin-releasing hormone and neurokinin B neurons. Eur. J. Neurosci. 2010, 11, 1984-1998. [CrossRef] [PubMed]

25. Yip, S.H.; Boehm, U.; Herbison, A.E.; and Campbell, R.E. Conditional viral tract tracing delineates the projections of the distinct kisspeptin neuron populations to gonadotropin-releasing hormone (GnRH) neurons in the mouse. Endocrinololy 2015, 156, 2582-2594. [CrossRef]

26. Lehman, M.N.; Coolen, L.M.; Goodman, R.L. Minireview: Kisspeptin/neurokinin B/dynorphin (KNDy) cells of the arcuate nucleus: A central node in the control of gonadotropin-releasing hormone secretion. Endocrinology 2010, 151, 3479-3489. [CrossRef]

27. Moore, A.M.; Coolen, L.M.; Porter, D.T.; Goodman, R.L.; Lehman, M.N. KNDy cells revisited. Endocrinology 2018, 159, 3219-3234. [CrossRef]

28. Morale, M.C.; Batticane, N.; Bartoloni, G.; Guarcello, V.; Farinella, Z.; Galasso, M.G.; Marchetti, B. Blocade of central and peripheral luteinizing hormone-releasing hormone (LHRH) receptors in neonatal rats with a potent LHRH-antagonist inhibits the morphofunctional development of the thymus and maturation of the cell-mediated and humoral immune responses. Endocrinology 1991, 128, 1073-1085. [CrossRef]

29. Dubois, E.A.; Zandbergen, M.A.; Peute, J.; Goos, H.J. Evolutionary development of three gonadotropin releasing hormone (GnRH) systems in vertebrates. Brain Res. Bull. 2002, 57, 413-418. [CrossRef]

30. Millar, R.P. GnRHs and GnRH Receptors. Anim. Reprod. Sci. 2005, 88, 5-28. [CrossRef]

31. Wu, H.M.; Wang, H.S.; Huang, H.Y.; Soong, Y.K.; MacCalman, C.D.; Leung, P.C. GnRH signaling in intrauterine tissues. Reproduction 2009, 137, 769-777. [CrossRef]

32. Millar, R.P.; Lu, Z.L.; Pawson, A.J.; Flanagan, C.A.; Morgan, K.; Maudsley, S.R. Gonadotropin-releasing hormone receptors. Endocr. Rev. 2004, 25, 235-275. [CrossRef] [PubMed]

33. Ramakrishnappa, N.; Rajamahendran, R.; Lin, Y.M.; Leung, P. C: GnRH in non-hypothalamic reproductive tissues. Anim. Reprod. Sci. 2005, 88, 95-113. [CrossRef] [PubMed]

34. Walters, K.; Wegorzewska, I.N.; Chin, Y.P.; Parikh, M.G.; Wu, T.J. Luteinizing hormone-releasing hormone I (LHRH-I) and its metabolite in peripheral tissues. Exp. Biol. Med. 2008, 233, 123-130. [CrossRef] [PubMed]

35. Tanriverdi, F.; Silveira, L.F.G.; MacColl, G.S.; Bouloux, P.M.G. The hypothalamic-pituitary-gonadal axis: Immune function and autoimmunity. J. Endocrinol. 2003, 176, 293-304. [CrossRef]

36. Bornstein, S.R.; Rutkowski, H.; Vrezas, I. Cytokines and steroidogenesis. Mol. Cell. Endocrinol. 2004, 215, 135-141. [CrossRef]

37. Sharova, V.S.; Izvolskaia, M.S.; Zakharova, L.A. Lipopolysaccharide-induced maternal inflammation affects the gonadotropinreleasing hormone neuron development in fetal mice. Neuroimmunomodulation 2015, 22, 222-232. [CrossRef]

38. Turnbull, A.V.; Rivier, C.L. Regulation of the hypothalamic-pituitary-adrenal axis by cytokines: Actions and mechanisms of action. Physiol. Rev. 1999, 79, 1-71. [CrossRef]

39. Barabás, K.; Szabó-Meleg, E.; Ábrahám, I.M. Effect of inflammation on female Gonadotropin-Releasing Hormone (GnRH) neurons: Mechanisms and consequences. Int. J. Mol. Sci. 2020, 21, 529. [CrossRef]

40. Zuckerman, L.; Weiner, I. Maternal immune activation leads to behavioral and pharmacological changes in the adult offspring. $J$. Psychiatr. Res. 2005, 39, 311-323. [CrossRef]

41. Liverman, C.S.; Kaftan, H.A.; Cui, L.; Hersperger, S.G.; Taboada, E.; Klein, R.M.; Berman, N.E. Altered expression of pro-inflammatory and developmental genes in the fetal brain in a mouse model of maternal infection. Neurosci. Lett. 2006, 399, 220-225. [CrossRef]

42. Wang, X.; Hagberg, H.; Zhu, C.; Jacobsson, B.; Mallard, C. Effects of intrauterine inflammation on the developing mouse brain. Brain Res. 2007, 1144, 180-185. [CrossRef] [PubMed]

43. Wang, S.; Yan, J.Y.; Lo, Y.K.; Carvey, P.M.; Ling, Z. Dopaminergic and serotoninergic deficiencies in young adult rats prenatally exposed to the bacterial lipopolysaccharide. Brain Res. 2009, 1265, 196-204. [CrossRef] [PubMed] 
44. Kirsten, T.B.; Chaves, G.P.; Taricano, M.; Martins, D.O.; Flório, J.C.; Britto, L.R.; Torrão, A.S.; Palermo-Neto, J.; Bernardi, M.M. Prenatal LPS exposure reduces olfactory perception in neonatal and adult rats. Physiol. Behav. 2011, 104, 417-422. [CrossRef] [PubMed]

45. Clark, L.F.; Kodadek, T. The Immune System and Neuroinflammation as Potential Sources of Blood-Based Biomarkers for Alzheimer's Disease, Parkinson's Disease, and Huntington's Disease. ACS Chem. Neurosci. 2016, 7, 520-527. [CrossRef]

46. Ardalan, M.; Chumak, T.; Vexler, Z.; Mallard, C. Sex-Dependent Effects of Perinatal Inflammation on the Brain: Implication for Neuro-Psychiatric Disorders. Int. J. Mol. Sci. 2019, 20, 2270. [CrossRef]

47. Izvolskaia, M.S.; Sharova, V.S.; Zakharova, L.A. Perinatal Inflammation Reprograms Neuroendocrine, Immune, and Reproductive Functions: Profile of Cytokine Biomarkers. Inflammation 2020, 43, 1175-1183. [CrossRef]

48. Straley, M.E.; Togher, K.L.; Nolan, A.M.; Kenny, L.C.; O'Keeffe, G.W. LPS alters placental inflammatory and endocrine mediators and inhibits fetal neurite growth in affected offspring during late gestation. Placenta 2014, 35, 533-538. [CrossRef]

49. Wang, H.; Yang, L.L.; Hu, Y.F.; Wang, B.W.; Huang, Y.Y.; Zhang, C.; Chen, Y.H.; Xu, D.X. Maternal LPS exposure during pregnancy impairs testicular development, steroidogenesis and spermatogenesis in male offspring. PLoS ONE 2014, 9, e106786. [CrossRef]

50. Izvolskaia, M.S.; Tillet, Y.; Sharova, V.S.; Voronova, S.N.; Zakharova, L.A. Disruptions in the hypothalamic-pituitary-gonadal axis in rat offspring following prenatal maternal exposure to lipopolysaccharide. Stress 2016, 19, 198-205. [CrossRef]

51. Izvolskaia, M.S.; Sharova, V.S.; Ignatiuk, V.M.; Voronova, S.N.; Zakharova, L.A. Abolition of prenatal lipopolysaccharide-induced reproductive disorders in rat male offspring by fulvestrant. Andrologia 2019, 51, e13204. [CrossRef]

52. Ignatiuk, V.M.; Izvolskaya, M.S.; Sharova, V.S.; Voronova, S.N.; Zakharova, L.A. Disruptions in the reproductive system of female rats after prenatal lipopolysaccharide-induced immunological stress: Role of sex steroids. Stress 2019, 22, 133-141. [CrossRef] [PubMed]

53. Lysenko, L.A. Back to anthropology: What does it mean to development studies? Beacon. J. Stud. Ideol. Ment. Dimens. 2019, 2, 020000000. Available online: https:/ / hdl.handle.net/20.500.12656/thebeacon.2.020000000 (accessed on 22 December 2020).

54. Sassin, W. Deja Vue. Beacon. J. Stud. Ideol. Ment. Dimens. 2019, 2, 020210216. Available online: https://hdl.handle.net/20.500.126 56/thebeacon.2.020210216 (accessed on 22 December 2020).

55. Sassin, W. Er-Schöpfung der Schöpfung, oder Eine neue Kulturstufe in der Entwicklung des homo. Beacon. J. Stud. Ideol. Ment. Dimens. 2019, 2, 020510203. Available online: https://hdl.handle.net/20.500.12656/thebeacon.2.020510203. (accessed on 22 December 2020). (In German).

56. Sassin, W. Die Grenzen der Ökonomie: Globalisierung-Vom Füllhorn zum Giftbecher? Eur. Crossrd. 2020, 1, 010410216. Available online: https:/ / hdl.handle.net/20.500.12656/eurcrossrd.1.010410216. (accessed on 22 December 2020). (In German).

57. Vitkovic, L.; Konsman, J.P.; Bockaert, J.; Dantzer, R.; Homburger, V.; Jacque, C. Cytokine signals propagate through the brain. Mol. Psychiatry 2000, 5, 604-615. [CrossRef]

58. Prinz, M.; Priller, J. The role of peripheral immune cells in the CNS in steady state and disease. Nat. Neurosci. 2017, 20, 136-144. [CrossRef]

59. McCann, S.M.; Kimura, M.; Karanth, S.; Yu, W.H.; Mastronardi, C.A.; Rettori, V. The mechanism of action of cytokines to control the release of hypothalamic and pituitary hormones in infection. Ann. N. Y. Acad. Sci. 2000, 917, 4-18. [CrossRef]

60. Igaz, P.; Salvi, R.; Rey, J.P.; Glauser, M.; Pralong, F.P.; Gaillard, R.C. Effects of cytokines on gonadotropin-releasing hormone $(\mathrm{GnRH})$ gene expression in primary hypothalamic neurons and in GnRH neurons immortalized conditionally. Endocrinology. 2006, 147, 1037-1043. [CrossRef]

61. Yoshida, K.; Tobet, S.A.; Crandall, J.E.; Jimenez, T.P.; Schwarting, G.A. The migration of luteinising hormone-releasing hormone neurons in the developing rat is associated with a transient, caudal projection of the vomeronasal nerve. J. Neurosci. 1995, 15, 7769-7777. [CrossRef]

62. Parkash, J.; Cimino, I.; Ferraris, N.; Casoni, F.; Wray, S.; Cappy, H.; Prevot, V.; Giacobini, P. Suppression of $\beta 1-$ Integrin in gonadotropin-releasing hormone cells disrupts migration and axonal extension resulting in severe reproductive alterations. $J$. Neurosci. 2012, 32, 16992-17002. [CrossRef] [PubMed]

63. Matsumoto, S.; Yamazaki, C.; Masumoto, K.H.; Nagano, M.; Naito, M.; Soga, T.; Hiyama, H.; Matsumoto, M.; Takasaki, J.; Kamohara, M.; et al. Abnormal development of the olfactory bulb and reproductive system in mice lacking prokineticin receptor PKR2. Proc. Natl. Acad. Sci. USA 2006, 103, 4140-4145. [CrossRef] [PubMed]

64. Yoshida, K.; Rutishauser, U.; Crandall, J.E.; Schwarting, G.A. Polysialic acid facilitates migration of luteinezing hormone-releasing hormone neurons on vomeronasal nerve. J. Neurosci. 1999, 19, 794-801. [CrossRef]

65. Battista, D.; Rutishauser, U. Removal of polysialic acid triggers dispersion of subventricularly derived neuroblasts into surrounding CNS tissues. J. Neurosci. 2010, 30, 3995-4003. [CrossRef] [PubMed]

66. Huilgol, D.; Tole, S. Cell migration in the developing rodent olfactory system. Cell. Mol. Life Sci. 2016, 73, 2467-2490. [CrossRef]

67. Tobet, S.A.; Crandall, J.E.; Schawrting, G.A. Relationship of migrating luteinezing hormone-releasing hormone neurons to unique olfactory system of glycoconjugates in embryonic rats. Dev. Biol. 1993, 155, 471-482. [CrossRef]

68. Fueshko, S.; Wray, S. LHRH cells migrate on periferin fibres in embryonic olfactory explant cultures: An in vitro model for neurotrophic migration. Dev. Biol. 1994, 166, 331-348. [CrossRef]

69. Rasterkamp, R.J.; Ruitenberg, M.J.; Verhaagen, J. Semaphorins and their receptors in olfactory axon guidance. Cell Mol. Biol. 2006, 45, 763-779. 
70. Lettieri, A.; Oleari, R.; Gimmelli, J.; ANDRe, V.; Cariboni, A. The role of semaphorin signaling in the etiology of hypogonadotropic hypogonadism. Minerva Endocrinol. 2016, 41, 266-278.

71. Känsäkosk, J.; Fagerholm, R.; Laitinen, E.M.; Vaaralahti, K.; Hackman, P.; Pitteloud, N.; Raivio, T.; Tommiska, J. Mutation screening of SEMA3A and SEMA7A in patients with congenital hypogonadotropic hypogonadism. Pediatr. Res. 2014, 75, 641-644. [CrossRef]

72. Marcos, S.; Monnier, C.; Rovira, X.; Fouveaut, C.; Pitteloud, N.; Ango, F.; Dodé, C.; Hardelin, J.-P. Defective signaling through plexin-A1 compromises the development of the peripheral olfactory system and neuroendocrine reproductive axis in mice. Hum. Mol. Genet. 2017, 26, 2006-2017. [CrossRef] [PubMed]

73. Cariboni, A.; Andrews, W.D.; Memi, F.; Ypsilanti, A.R.; Zelina, P.; Chedotal, A.; Parnavelas, J.G. Slit2 and Robo3 modulate the migration of GnRH-secreting neurons. Development 2012, 139, 3326-3331. [CrossRef] [PubMed]

74. Taroc, E.Z.M.; Lin, J.M.; Tulloch, A.J.; Jaworski, A.; Forni, P.E. GnRH-1 neural migration from the nose to the brain is independent from Slit2, Robo3 and NELL2 signaling. Front. Cell Neurosci. 2019, 13, 70. [CrossRef]

75. Bless, E.P.; Walker, H.J.; Yu, K.W.; Knoll, J.G.; Moenter, S.M.; Schwarting, G.A.; Tobet, S.A. Live view of gonadotropin-releasing hormone containing neuron migration. Endocrinology 2005, 146, 463-468. [CrossRef]

76. Cariboni, A.; Rakic, S.; Liapi, A.; Maggi, R.; Goffinet, A.; Parnavelas, J.G. Reelin provides an inhibitory signal in the migration of gonadotropin-releasing hormone neurons. Development 2005, 132, 4709-4718. [CrossRef]

77. Shu, T.; Valentino, K.M.; Seaman, C.; Cooper, H.M.; Richards, L.J. Expression of the netrin-1 receptor, deleted in colorectal cancer (DCC), is largely confined to projecting neurons in the developing forebrain. J. Comp. Neurol. 2000, 406, 201-212. [CrossRef]

78. Schwarting, G.A.; Raitcheva, D.; Bless, E.P.; Ackerman, S.L.; Tobet, S. Netrin 1-mediated chemoattraction regulates the migratory pathway of LHRH neurons. Eur. J. Neurosci. 2004, 19, 11-20. [CrossRef]

79. Giacobini, P.; Messina, A.; Wray, S.; Giampietro, C.; Crepaldi, T.; Carmeliet, P.; Fasolo, A. Hepatocyte growth factor acts as a motogen and guidance signal for gonadotropin hormone-releasing hormone-1 neuronal migration. J. Neurosci. 2007, 10, 431-445. [CrossRef]

80. Toba, Y.; Tiong, J.D.; Ma, Q.; Wray, S. CXCR4/SDF-1 system modulates development of GnRH-1 neurons and the olfactory system. Dev. Neurobiol. 2008, 68, 487-503. [CrossRef]

81. Kawaguchi, N.; Zhang, T.T.; Nakanishi, T. Involvement of CXCR4 in normal and abnormal development. Cells 2019, 8, 185. [CrossRef]

82. Dozio, E.; Ruscica, M.; Galliera, E.; Corsi, M.M.; Magni, P. Leptin, ciliary neurotrophic factor, leukemia inhibitory factor and interleukin-6: Class I cytokines involved in the neuroendocrine regulation of the reproductive function. Curr. Protein Pept. Sci. 2009, 10, 577-584. [CrossRef]

83. Magni, P.; Dozio, E.; Ruscica, M.; Watanobe, H.; Cariboni, A.; Zaninetti, R.; Motta, M.; Maggi, R. Leukemia inhibitory factor induces the chemomigration of immortalized gonadotropin-releasing hormone neurons through the independent activation of the Janus kinase/signal transducer and activator of transcription 3, mitogen-activated protein kinase/extracellularly regulated kinase 1/2, and phosphatidylinositol 3-kinase/Akt signaling pathways. Mol. Endocrinol. 2007, 21, 1163-1174. [CrossRef]

84. Chattopadhyay, N.; Jeong, K.H.; Yano, S.; Huang, S.; Pang, J.L.; Ren, X.; Terwilliger, E.; Kaiser, U.B.; Vassilev, P.M.; Pollak, M.R.; et al. Calcium receptor stimulates chemotaxis and secretion of MCP-1 in GnRH neurons in vitro: Potential impact on reduced GnRH neuron population in CaR-null mice. Am. J. Physiol. Endocrinol. Metab. 2007, 292, 523-532. [CrossRef]

85. Eddie, S.L.; Childs, A.J.; Jabbour, H.N.; Anderson, R.A. Developmentally regulated IL6-type cytokines signal to germ cells in the human fetal ovary. Mol. Hum. Reprod. 2012, 18, 88-95. [CrossRef] [PubMed]

86. Cheng, L.; Gearing, D.P.; White, L.S.; Compton, D.L.; Schooley, K.; Donovan, P.J. Role of leukemia inhibitory factor and its receptor in mouse primordial germ cell growth. Development 1994, 120, 3145-3153.

87. Simamura, E.; Shimada, H.; Higashi, N.; Uchishiba, M.; Otani, H.; Hatta, T. Maternal leukemia inhibitory factor (LIF) promotes fetal neurogenesis via LIF-ACTH-LIF signaling relay pathway. Endocrinology 2010, 151, 1853-1862. [CrossRef]

88. Dahlgren, J.; Samuelsson, A.M.; Jansson, T.; Holmäng, A. Interleukin-6 in the maternal circulation reaches the rat fetus in mid-gestation. Pediatr. Res. 2006, 60, 147-151. [CrossRef] [PubMed]

89. Wu, S.; Wolfe, A. Signaling of cytokines is important in regulation of GnRH neurons. Mol. Neurobiol. 2012, 45, 119-125. [CrossRef] [PubMed]

90. Bless, E.P.; Westaway, W.A.; Schwarting, G.A.; Tobet, S.A. Effects of gamma-aminobutyric acid (A) receptor manipulation on migrating gonadotropin-releasing hormone neurons through the entire migratory route in vivo and in vitro. Endocrinology 2000, 141, 1254-1262. [CrossRef]

91. Liu, X.; Porteous, R.; Herbison, A.E. Dynamics of GnRH neuron ionotropic GABA and glutamate synaptic receptors are unchanged during estrogen positive and negative feedback in female mice. eNeuro 2017, 4, 29109970. [CrossRef]

92. Vastagh, C.; Schwirtlich, M.; Kwakowsky, A.; Erdélyi, F.; Margolis, F.L.; Yanagawa, Y.; Katarova, Z.; Szabó, G. The spatiotemporal segregation of GAD forms defines distinct GABA signaling functions in the developing mouse olfactory system and provides novel insights into the origin and migration of GnRH neurons. Dev. Neurobiol. 2015, 75, 249-270. [CrossRef] [PubMed]

93. Izvolskaia, M.; Duittoz, A.H.; Tillet, Y.; Ugrumov, M.V. The influence of catecholamine on the migration of gonadotropin-releasing hormone-producing neurons in the rat foetuses. Brain Struct. Funct. 2009, 938, 289-300. [CrossRef] [PubMed]

94. Melnikova, V.I.; Afanasyeva, M.A.; Voronova, S.N.; Zakharova, L.A. The effect of catecholamine deficit on the development of the immune system in rats. Dokl. Biol. Sci. 2012, 443, 68-70. [CrossRef] 
95. Lifantseva, N.V.; Koneeva, T.O.; Voronova, S.N.; Zakharova, L.A.; Melnikova, V.I. The inhibition of dopamine synthesis in fetuses changes the pattern of T-lymphocyte maturation in the thymus of adult rats. Dokl. Biochem. Biophys. 2016, 470, 342-344. [CrossRef]

96. Forni, P.E.; Taylor-Burds, C.; Melvin, V.S.; Williams, T.; Wray, S. Neural crest and ectodermal cells intermix in the nasal placode to give rise to GnRH-1 neurons, sensory neurons, and olfactory ensheathing cells. J. Neurosci. 2011, 31, 6915-6927. [CrossRef]

97. Chen, S.Y.; Cheng, A.M.S.; Zhang, Y.; Zhu, Y.T.; He, H.; Mahabole, M.; Tseng, S.C.G. Pax 6 controls neural crest potential of limbal niche cells to support self-renewal of limbal epithelial stem cells. Sci. Rep. 2019, 9, 9763. [CrossRef]

98. Ikeda, K.; Watanabe, Y.; Ohto, H.; Kawakami, K. Molecular interaction and synergistic activation of a promoter by Six, Eya, and Dach proteins mediated through CREB binding protein. Mol. Cell. Biol. 2002, 22, 6759-6766. [CrossRef]

99. Abitua, P.B.; Gainous, T.B.; Kaczmarczyk, A.N.; Winchell, C.J.; Hudson, C.; Kamata, K.; Nakagawa, M.; Tsuda, M.; Kusakabe, T.G.; Levine, M. The pre-vertebrate origins of neurogenic placodes. Nature 2015, 524, 462-465. [CrossRef]

100. Larder, R.; Clark, D.D.; Miller, N.L.G.; Mellon, P.M. Hypothalamic dysregulation and infertility in mice lacking the homeodomain protein Six 6. J. Neurosci. 2011, 31, 426-438. [CrossRef]

101. Ikeda, K.; Ookawara, S.; Sato, S.; Ando, Z.; Kageyama, R.; Kawakami, K. Six1 is essential for early neurogenesis in the development of olfactory epithelium. Dev. Biol. 2007, 311, 53-68. [CrossRef]

102. Simeone, A.; Acampora, D. The role of Otx2 in organizing the anterior patterning in mouse. Int. J. Dev.Biol. 2001, 45, 337-345. [PubMed]

103. Hoffmann, H.M.; Larder, R.; Lee, J.S.; Hu, R.J.; Trang, C.; Devries, B.M.; Clark, D.D.; Mellon, P.L. Differential CRE Expression in Lhrh-cre and GnRH-cre Alleles and the Impact on Fertility in Otx2-Flox Mice. Neuroendocrinology 2019, 108, 328-342. [CrossRef] [PubMed]

104. Quaynor, S.D.; Bosley, M.E.; Duckworth, C.G.; Porter, K.R.; Kim, S.H.; Kim, H.G.; Chorich, L.P.; Sullivan, M.E.; Choi, J.H.; Cameron, R.S.; et al. Targeted next generation sequencing approach identifies eighteen new candidate genes in normosmic hypogonadotropic hypogonadism and Kallmann syndrome. Mol Cell Endocrinol. 2016, 437, 86-96. [CrossRef] [PubMed]

105. Taroc, E.Z.M.; Naik, A.S.; Lin, J.M.; Peterson, N.B.; Keefe, D.L., Jr.; Genis, L.; Fuchs, G.; Balasubramanian, R.; Forni, P.E. Gli3 Regulates Vomeronasal Neurogenesis, Olfactory Ensheathing Cell Formation, and GnRH-1 Neuronal Migration. J. Neurosci. 2020, 40, 311-326. [CrossRef] [PubMed]

106. Corradi, A.; Croci, L.; Broccoli, V.; Zecchini, S.; Previtali, S.; Wurst, W.; Amadio, S.; Maggi, R.; Quattrini, A.; Consalez, G.G. Hypogonadotropic hypogonadism and peripheral neuropathy in Ebf2-null mice. Development 2003, 130, 401-410. [CrossRef] [PubMed]

107. Trarbach, E.B.; Baptista, M.T.; Garmes, H.M.; Hackel, C. Molecular analysis of KAL-1, GnRH-R, NELF and EBF2 genes in a series of Kallmann syndrome and normosmic hypogonadotropic hypogonadism patients. J. Endocrinol. 2005, 187, 361-368. [CrossRef] [PubMed]

108. Cogliati, T.; Delgado-Romero, P.; Norwitz, E.R.; Guduric-Fuchs, J.; Kaiser, U.B.; Wray, S.; Kirsch, I.R. Pubertal impairment in Nhlh2 null mice is associated with hypothalamic and pituitary deficiencies. Mol. Endocrinol. 2007, 21, 3013-3027. [CrossRef]

109. Schmid, T.; Boehm, U.; Braun, T. GnRH neurogenesis depends on embryonic pheromone receptor expression. Mol. Cell. Endocrinol. 2020, 518, 111030. [CrossRef]

110. Taglialatela, P.; Soria, J.M.; Caironi, V.; Moiana, A.; Bertuzzi, S. Compromised generation of GABAergic interneurons in the brains of Vax1 $1^{-/-}$mice. Development 2004, 131, 4239-4249. [CrossRef]

111. Hoffmann, H.M.; Mellon, P.L. A small population of hypothalamic neurons govern fertility: The critical role of VAX1 in GnRH neuron development and fertility maintenance. Neurosci. Commun. (Houst.) 2016, 2, e1373.

112. Cau, E.; Casarosa, S.; Guillemot, F. Mash1 and Ngn1 control distinct steps of determination and differentiation in the olfactory sensory neuron lineage. Development 2002, 129, 1871-1880. [PubMed]

113. Kramer, P.K.; Guerrero, G.; Krishnamurthy, R.; Mitchel, P.J.; Wray, S. Ectopic expression of LHRH and periferin in the respiratory epithelium of mice lacing transcriptional factor AP-2. Mech. Dev. 2000, 94, 79-94. [CrossRef]

114. Leclerc, G.M.; Bose, S.K.; Boockfor, F.R. Specific GATA-binding elements in the GnRH promoter are required for gene expression pulse activity: Role of GATA-4 and GATA-5 in this intermittent process. Neuroendocrinology 2008, 88, 1-16. [CrossRef] [PubMed]

115. Balasubramanian, R.; Crowley, W.F., Jr. Isolated GnRH deficiency: A disease model serving as a unique prism into the systems biology of the GnRH neuronal network. Mol. Cell. Endocrinol. 2011, 346, 4-12. [CrossRef] [PubMed]

116. Wu, X.Q.; Li, X.F.; Ye, B.; Popat, N.; Milligan, S.R.; Lightman, S.L.; O’Byrne, K.T. Neonatal programming by immunological challenge: Effects on ovarian function in the adult rat. Reproduction 2011, 41, 241-248. [CrossRef]

117. Sharova, V.S.; Izvol'skaia, M.S.; Voronova, S.N.; Zakharova, L.A. Effect of bacterial endotoxin on migration of gonadotropinreleasing, hormone producing neurons in rat embryogenesis. Ontogenez 2011, 42, 439-446. [CrossRef]

118. Cadman, S.M.; Kim, S.H.; Hu, Y.; González-Martínez, D.; Bouloux, P.M. Molecular pathogenesis of Kallmann's syndrome. Horm. Res. 2007, 67, 231-242. [CrossRef]

119. Gianetti, E.; Tusset, C.; Noel, S.D.; Au, M.G.; Dwyer, A.A.; Hughes, V.A.; Crowley, W.F.; Kaiser, U.B.; Latronico, A.C.; Seminara, S.B. TAC3/TACR3 mutations reveal preferential activation of gonadotropin-releasing hormone release by neurokinin B in neonatal life followed by reversal in adulthood. J. Clin. Endocrinol. Metab. 2010, 95, 2857-2867. [CrossRef]

120. Shaw, N.D.; Seminara, S.B.; Welt, C.K.; Au, M.G.; Plummer, L.; Hughes, V.A.; Dwyer, A.A.; Martin, K.A.; Quinton, R.; Mericq, V.; et al. Expanding the phenotype and genotype of female GnRH deficiency. J. Clin. Endocrinol. Metab. 2011, 96, 566-576. [CrossRef] 
121. Drummond, E.S.; Martins, R.N.; Handelsman, D.J.; Harvey, A.R. Altered expression of Alzheimer's disease-related proteins in male hypogonadal mice. Endocrinology 2012, 153, 2789-2799. [CrossRef]

122. Lillycrop, K.A.; Slater-Jefferies, J.L.; Hanson, M.A.; Godfrey, K.M.; Jackson, A.A.; Burdge, G.C. Induction of altered epigenetic regulation of the hepatic glucocorticoid receptor in the offspring of rats fed a protein-restricted diet during pregnancy suggests that reduced DNA methyltransferase-1 expression is involved in impaired DNA methylation and changes in histone modifications. Br. J. Nutr. 2007, 97, 1064-1073. [CrossRef] [PubMed]

123. Aiken, C.E.; Ozann, S.E. Sex differences in developmental programming models. Reproduction 2013, 145, R1-R13. [CrossRef] [PubMed]

124. Cameron, N.M.; Shahrokh, D.; Del Corpo, A.; Dhir, S.K.; Szyf, M.; Champagne, F.A.; Meaney, M.J. Epigenetic programming of phenotypic variations in reproductive strategies in the rat through maternal care. J. Neuroendocrinol. 2008, 20, 795-801. [CrossRef] [PubMed]

125. Champagne, F.A.; Curley, J.P. Maternal regulation of estrogen receptor alpha methylation. Curr. Opin. Pharmacol. 2008, 8, 735-739. [CrossRef]

126. Tomikawa, J.; Uenoyama, Y.; Ozawa, M.; Fukanuma, T.; Takase, K.; Goto, T.; Okamura, H.; Maeda, K.; Tsukamura, H. Epigenetic regulation of Kiss1 gene expression mediating estrogen-positive feedback action in the mouse brain. Proc. Natl. Acad. Sci. USA 2012, 109, E1294-E1301. [CrossRef]

127. Knox, A.M.; Li, X.F.; Kinsey-Jones, J.S.; Wilkinson, E.S.; Wu, X.Q.; Cheng, Y.S.; Milligan, S.R.; Lightman, S.L.; O’Byrne, K.T Neonatal lipopolysaccharide exposure delays puberty and alters hypothalamic Kiss1 and Kiss1r mRNA expression in the female rat. J. Neuroendocrinol. 2009, 21, 683-692. [CrossRef]

128. Bryan, E.R.; Kim, J.; Beagley, K.W.; Carey, A.J. Testicular inflammation and infertility: Could chlamydial infections be contributing? Am. J. Reprod. Immunol. 2020, 84, e13286. [CrossRef]

129. Cai, Z.; Pan, Z.L.; Pang, Y.; Evans, O.B.; Rhodes, P.G. Cytokine induction in fetal rat brains and brain injury in neonatal rats after maternal lipopolysaccharide administration. Pediatr. Res. 2000, 47, 64-72. [CrossRef]

130. Gilstrap, L.C.; Ramin, S.M. Urinary tract infections during pregnancy. Obstet. Gynecol. Clin. N. Am. 2001, 28, 581-591. [CrossRef]

131. Hagberg, H.; Gressens, P.; Mallard, C. Inflammation during fetal and neonatal life: Implications for neurologic and neuropsychiatric disease in children and adults. Ann. Neurol. 2012, 71, 444-457. [CrossRef]

132. Wang, H.L.; Pei, D.E.; Yang, R.D.; Wan, C.L.; Ye, Y.M.; Peng, S.S.; Zeng, Q.Q.; Yu, Y. Prenatal maternal vaginal inflammation increases anxiety and alters HPA axis signalling in adult male mice. Int. J. Dev. Neurosci. 2019, 75, 27-35. [CrossRef] [PubMed]

133. Herman, A.P.; Tomaszewska-Zaremba, D. Effect of endotoxin on the expression of GnRH and GnRHR genes in the hypothalamus and anterior pituitary gland of anestrous ewes. Anim. Reprod. Sci. 2010, 120, 105-111. [CrossRef] [PubMed]

134. Watanobe, H.; Hayakawa, Y. Hypothalamic Interleukin-1 and Tumor Necrosis Factor, but not Interleukin-6, mediate the endotoxininduced suppression of the reproductive axis in rats. Endocrinology 2003, 144, 4868-4875. [CrossRef] [PubMed]

135. Jurewicz, A.; Matysiak, M.; Tybor, K.; Kilianek, L.; Raine, C.S.; Selmaj, K. Tumour necrosis factor-induced death of adult human oligodendrocytes is mediated by apoptosis inducing factor. Brain 2005, 128, 2675-2688. [CrossRef] [PubMed]

136. Kothari, N.; Bogra, J.; Abbas, H.; Kohli, M.; Malik, A.; Kothari, D.; Srivastav, S.; Singh, P.K. Tumor necrosis factor gene polymorphism results in high TNF level in sepsis and septic shock. Cytokine 2013, 61, 676-681. [CrossRef] [PubMed]

137. Ginsberg, Y.; Khatib, N.; Weiner, Z.; Beloosesky, R. Maternal inflammation, fetal brain implications and suggested neuroprotection: A summary of 10 years of research in animal models. Rambam Maimonides Med. J. 2017, 8, e0028. [CrossRef]

138. Kalra, P.S.; Edwards, T.G.; Xu, B.; Jain, M.; Kalra, S.P. The anti-gonadotropic effects of cytokines: The role of neuropeptides. Domes. Anim. Endocrinol. 1998, 15, 321-332. [CrossRef]

139. Nouel, D.; Burt, M.; Zhang, Y.; Harvey, L.; Boksa, P. Prenatal exposure to bacterial endotoxin reduces the number of GAD67- and reelin-immunoreactive neurons in the hippocampus of rat offspring. Eur. Neuropsychopharmacol. 2012, 22, 300-307. [CrossRef]

140. Harvey, L.; Boksa, P. A stereological comparison of GAD67 and reelin expression in the hippocampal stratum oriens of offspring from two mouse models of maternal inflammation during pregnancy. Neuropharmacology 2012, 62, 1767-1776. [CrossRef]

141. Morale, M.C.; Gallo, F.; Tirolo, C.; L’Episcopo, F.; Gennuso, F.; Testa, N.; Caniglia, S.; Spina-Purrello, V.; Avola, R.; Scoto, G.M.; et al The reproductive system at the neuroendocrine-immune interface: Focus on LHRH, estrogens and growth factors in LHRH neuron-glial interactions. Domest. Anim. Endocrinol. 2003, 25, 21-46. [CrossRef]

142. Coe, C.L.; Lubach, G.R. Prenatal origins of individual variation in behavior and immunity. Neurosci. Biobehav. Rev. 2005, 29 , 39-49. [CrossRef] [PubMed]

143. Van den Bergh, B.R.H.; van den Heuvel, M.I.; Lahti, M.; Braeken, M.; de Rooij, S.R.; Entringer, S.; Hoyer, D.; Roseboom, T.; Räikkönen, K.; King, S.; et al. Prenatal developmental origins of behavior and mental health: The influence of maternal stress in pregnancy. Neurosci. Biobehav. Rev. 2020, 117, 26-64. [CrossRef] [PubMed]

144. Zakharova, L.A.; Malyukova, I.V.; Proshlyakova, E.V.; Sapronova, A.Y.; Ugrumov, M.V. Hypothalamo-pituitary control of the cell-mediated immunity in rat embryos: Role of LHRH in regulation of lymphocyte proliferation. J. Reprod. Immunol. 2000, 47, 17-32. [CrossRef]

145. Mann, D.R.; Akinbami, M.A.; Lunn, S.F.; Fraser, H.M.; Gould, K.G.; Ansari, A.A. Endocrine-immune interaction: Alteractions in immune function resulting from neonatal treatment with a $\mathrm{GnRH}$ antagonist and seasonality in male primates. Am. J. Reprod. Immunol. 2000, 44, 30-40. [CrossRef] [PubMed] 
146. Dygalo, N.N.; Shemenkova, T.V.; Kalinina, T.S.; Shishkina, G.T. A critical point of male gonad development: Neuroendocrine correlates of accelerated testicular growth in rats during early life. PLOS ONE 2014, 9, e93007. [CrossRef]

147. Rao, L.V.; Cleveland, R.P.; Kimmel, R.J.; Ataya, K.M. Hematopoietic stem cell antigen-1 (Sca-1) expression in different lymphoid tissues of female mice treated with GnRH agonist. Am. J. Reprod. Immunol. 1995, 34, 257-266. [CrossRef]

148. Ullewar, M.P.; Umathe, S.N. Gonadotropin-releasing hormone agonist selectively augments thymopoiesis and prevents cell apoptosis in LPS induced thymic atrophy model independent of gonadal steroids. Int. Immunopharmacol. 2014, 23 , 46-53. [CrossRef]

149. Jacobson, J.D.; Ansari, M.A.; Mansfield, M.E.; McArthur, C.P.; Clement, L. T Gonadotropin-releasing hormone increases CD4 T-lymphocyte numbers in an animal model of immunodeficiency. J. Allergy Clin. Immunol. 1999, 104, 653-658. [CrossRef]

150. Yarilin, A.A.; Belyakov, I.M. Cytokines in the thymus: Production and biological effects. Curr. Med. Chem. 2004, 11, 447-464. [CrossRef]

151. Beutler, B.A. The role of tumor necrosis factor in health and disease. J. Rheumatol. Suppl. 1999, 57, 16-21.

152. Metcalf, D. The unsolved enigmas of leukemia inhibitory factor. Stem Cells. 2003, 21, 5-14. [CrossRef] [PubMed]

153. Batticane, N.; Morale, M.C.; Gallo, F.; Farinella, Z.; Marchetti, B. Luteinizing hormone-releasing hormone signaling at the lymphocyte involves stimulation of interleukin-2 receptor expression. Endocrinology 1991, 129, 277-286. [CrossRef] [PubMed]

154. Tanriverdi, F.; Gonzalez-Martinez, D.; Hu, Y.; Kelestimur, F.P.; Bouloux, M.G. GnRH-I and GnRH-II have differential modulatory effects on human peripheral blood mononuclear cell proliferation and interleukin-2 receptor $\gamma$-chain mRNA expression in healthy males. Clin. Exp. Immunol. 2005, 142, 103-110. [CrossRef] [PubMed]

155. Tanriverdi, F.; Gonzalez-Martinez, D.; Silveira, L.F.; Hu, Y.; Maccoll, G.S.; Travers, P.; Bouloux, M.G. Expression of gonadotropinreleasing hormone type-I (GnRH-I) and type-II (GnRH-II) in human peripheral blood mononuclear cells (PMBCs) and regulation of B-lymphoblastoid cell proliferation by GnRH-I and GnRH-II. Exp. Clin. Endocrinol. Diabetes 2004, 112, 587-594. [CrossRef]

156. Montgomery, R.A.; Dallman, M.J. Analysis of cytokine gene expression during fetal thymic ontogeny using the polymerase chain reaction. J. Immunol. 1991, 147, 554-560.

157. Rouiller-Fabre, V.; Levacher, C.; Pairault, C.; Racine, C.; Moreau, E.; Olaso, R.; Livera, G.; Migrenne, S.; Delbes, G.; Habert, R. Development of the foetal and neonatal testis. Andrologia 2003, 35, 79-83. [CrossRef]

158. Azad, N.; LaPaglia, N.; Agrawal, L.; Steiner, J.; Uddin, S.; Williams, D.W.; Lawrence, A.M.; Emanuele, N.V. The role of gonadectomy and testosterone replacement on thymic luteinizing hormone-releasing hormone production. J. Endocrinol. 1998, 158, 229-235. [CrossRef]

159. Jacobson, J.D.; Ansari, M.A. Immunomodulatory actions of gonadal steroids may be mediated by gonadotropin-releasing hormone. Endocrinology 2004, 145, 330-336. [CrossRef]

160. Zandman-Goddard, G.; Peeva, E.; Shoenfeld, Y. Gender and autoimmunity. Autoimmun. Rev. 2007, 6, 366-372. [CrossRef]

161. Jacobson, J.D. Gonadotropin-releasing hormone and G proteins: Potential roles in autoimmunity. Ann. N. Y. Acad. Sci. 2000, 917, 809-818. [CrossRef]

162. Andersson, A.M.; Jørgensen, N.; Main, K.M.; Toppari, J.; Rajpert-De Meyts, E.; Leffers, H.; Skakkebaek, N.E. Adverse trends in male reproductive health: We may have reached a crucial 'tip- ping point'. Int. J. Androl. 2008, 31, 74-80. [CrossRef] [PubMed]

163. Glaser, A.P.; Schaeffer, A.J. Urinary Tract Infection and Bacteriuria in Pregnancy. Urol. Clin. N. Am. 2015, 42, 547-560. [CrossRef] [PubMed]

164. Nguyen, T.M.; Crowther, C.A.; Wilkinson, D.; Bain, E. Magnesium sulphate for women at term for neuroprotection of the fetus. Cochrane Database Syst. Rev. 2013, 2, CD009395. [CrossRef] [PubMed]

165. Beloosesky, R.; Khatib, N.; Ginsberg, Y.; Anabosy, S.; Shalom-Paz, E.; Dahis, M.; Ross, M.G.; Weiner, Z. Maternal magnesium sulfate fetal neuroprotective effects to the fetus: Inhibition of neuronal nitric oxide synthase and nuclear factor kappa-light-chainenhancer of activated B cells activation inthom. Am. J. Obstet. Gynecol. 2016, 215, 382e1-382e6. [CrossRef]

166. Sharabi, H.; Khatib, N.; Ginsberg, Y.; Weiner, Z.; Ross, M.G.; Tamar, B.K.; Efrat, S.; Mordechai, H.; Beloosesky, R. Therapeutic $\mathrm{N}$-Acetyl-Cysteine (Nac) Following Initiation of Maternal Inflammation Attenuates Long-Term Offspring Cerebral Injury, as Evident in Magnetic Resonance Imaging (MRI). Neuroscience 2019, 403, 118-124. [CrossRef]

167. Lappas, M.; Permezel, M.; Rice, G.E. N-acetyl-cysteine inhibits phospholipid metabolism, proinflammatory cytokine release, protease activity, and nuclear factor-kappaB deoxyribonucleic acid-binding activity in human fetal membranes in vitro. J. Clin. Endocrinol. Metab. 2003, 88, 1723-1729. [CrossRef]

168. Wang, H.; Hu, Y.F.; Hao, J.H.; Chen, Y.H.; Su, P.Y.; Wang, Y.; Yu, Z.; Fu, L.; Xu, Y.Y.; Zhang, C.; et al. Maternal zinc deficiency during pregnancy elevates the risks of fetal growth restriction: A population-based birth cohort study. Sci. Rep. 2015, 5, 11262. [CrossRef]

169. Chua, J.S.; Cowley, C.J.; Manavis, J.; Rofe, A.M.; Coyle, P. Prenatal exposure to lipopolysaccharide results in neurodevelopmental damage that is ameliorated by zinc in mice. Brain Behav. Immun. 2012, 26, 326-336. [CrossRef]

170. Labrousse, V.F.; Leyrolle, Q.; Amadieu, C.; Aubert, A.; Sere, A.; Coutureau, E.; Grégoire, S.; Bretillon, L.; Pallet, V.; Gressens, P.; et al. Dietary omega-3 deficiency exacerbates inflammation and reveals spatial memory deficits in mice exposed to lipopolysaccharide during gestation. Brain Behav. Immun. 2018, 7, 427-440. [CrossRef]

171. Zhou, Y.; Chen, Y.H.; Fu, L.; Yu, Z.; Xia, M.Z.; Hu, X.G.; Wang, H.; Xu, D.X. Vitamin D3 pretreatment protects against lipopolysaccharide-induced early embryo loss through its anti-inflammatory effects. Am. J. Reprod. Immunol. 2017, 77. [CrossRef] 
172. Maugeri, A.; Barchitta, M.; Blanco, I.; Agodi, A. Effects of Vitamin D Supplementation During Pregnancy on Birth Size: A Systematic Review and Meta-Analysis of Randomized Controlled Trials. Nutrients 2019, 11, 442. [CrossRef] [PubMed]

173. Langley-Evans, S.C. Developmental programming of health and disease. Proc. Nutr. Soc. 2006, 65, 97-105. [CrossRef] [PubMed]

174. Zhou, S.S.; Zhou, Y.M.; Li, D.; Ma, Q. Early Infant Exposure to Excess Multivitamin: A Risk Factor for Autism? Autism Res Treat. 2013, 2913, 963697. [CrossRef] [PubMed]

175. Sheppard, M.; Laskou, F.; Stapleton, P.P.; Hadavi, S.; Dasgupta, B. Tocilizumab (Actemra). Hum. Vaccin. Immunother. 2017, 13, 1972-1988. [CrossRef] [PubMed]

176. European Medicines Agency. 1st Edition. London, UK, 2009. Available online: https://www.ema.europa.eu/en/documents/ assessment-report/invokana-epar-public-assessment-report_en.pdf (accessed on 3 January 2017).

177. Smith, S.E.; Li, J.; Garbett, K.; Mirnics, K.; Patterson, P.H. Maternal immune activation alters fetal brain development through interleukin-6. J. Neurosci. 2007, 27, 10695-10702. [CrossRef]

178. Domínguez-Soto, Á.; Simón-Fuentes, M.; de Las Casas-Engel, M.; Cuevas, V.D.; López-Bravo, M.; Domínguez-Andrés, J.; Saz-Leal, P.; Sancho, D.; Ardavín, C.; Ochoa-Grullón, J.; et al. IVIg promote cross-tolerance against inflammatory stimuli in vitro and in vivo. J. Immunol. 2018, 201, 41-52. [CrossRef]

179. Sawa, T.; Kinoshita, M.; Inoue, K.; Ohara, J.; Moriyama, K. Immunoglobulin for treating bacterial infections: One more mechanism of action. Antibodies 2019, 8, 52. [CrossRef]

180. Inci, A.; Ûnal, D.S.; Ôzeş, N.O.; Erin, N.; Akçakuş, M.; Oygû́r, N. The efficacy of intravenous immunoglobulin on lipopolysaccharide-induced fetal brain inflammation in preterm rats. Am. J. Obstet. Gynecol. 2013, 209, 1-8. [CrossRef]

181. Kyvelidou, C.; Sotiriou, D.; Zerva, I.; Athanassakis, I. Protection against lipopolysaccharide-induced immunosuppression by IgG and IgM. Shock 2018, 49, 474-482. [CrossRef]

182. Chaigne, B.; Mouthon, L. Mechanisms of action of intravenous immunoglobulin. Transfus. Apher. Sci. 2017, 56, 45-49. [CrossRef]

183. Murakami, K.; Suzuki, C.; Kobayashi, F.; Nakano, A.; Fujii, A.; Sakai, K.; Imada, T. Intravenous immunoglobulin preparation attenuates LPS-induced production of pro-inflammatory cytokines in human monocytic cells by modulating TLR4-mediated signaling pathways. Naunyn Schmiedebergs Arch. Pharmacol. 2012, 385, 891-898. [CrossRef] [PubMed]

184. Anthoney, N.; Foldi, I.; Hidalgo, A. Toll and Toll-like receptor signalling in development. Development 2018, 145 , dev156018. [CrossRef] [PubMed] 